\title{
,nem \\ Roles of Podoplanin in Malignant Progression of Tumor
}

\author{
Hiroyuki Suzuki ${ }^{1, * \mathbb{D}}$, Mika K. Kaneko ${ }^{2}$ and Yukinari Kato ${ }^{1,2, * \mathbb{D}}$ \\ 1 Department of Molecular Pharmacology, Tohoku University Graduate School of Medicine, 2-1 Seiryo-machi, \\ Aoba-ku, Sendai 980-8575, Japan \\ 2 Department of Antibody Drug Development, Tohoku University Graduate School of Medicine, \\ 2-1 Seiryo-machi, Aoba-ku, Sendai 980-8575, Japan; k.mika@med.tohoku.ac.jp \\ * Correspondence: hiroyuki.suzuki.b4@tohoku.ac.jp (H.S.); yukinarikato@med.tohoku.ac.jp (Y.K.); \\ Tel.: +81-22-717-8207 (H.S. \& Y.K.)
}

\begin{abstract}
Podoplanin (PDPN) is a cell-surface mucin-like glycoprotein that plays a critical role in tumor development and normal development of the lung, kidney, and lymphatic vascular systems. PDPN is overexpressed in several tumors and is involved in their malignancy. PDPN induces platelet aggregation through binding to platelet receptor C-type lectin-like receptor 2. Furthermore, PDPN modulates signal transductions that regulate cell proliferation, differentiation, migration, invasion, epithelial-tomesenchymal transition, and stemness, all of which are crucial for the malignant progression of tumor. In the tumor microenvironment (TME), PDPN expression is upregulated in the tumor stroma, including cancer-associated fibroblasts (CAFs) and immune cells. CAFs play significant roles in the extracellular matrix remodeling and the development of immunosuppressive TME. Additionally, PDPN functions as a co-inhibitory molecule on T cells, indicating its involvement with immune evasion. In this review, we describe the mechanistic basis and diverse roles of PDPN in the malignant progression of tumors and discuss the possibility of the clinical application of PDPN-targeted cancer therapy, including cancer-specific monoclonal antibodies, and chimeric antigen receptor $\mathrm{T}$ technologies.
\end{abstract}

check for

updates

Citation: Suzuki, H.; Kaneko, M.K.;

Kato, Y. Roles of Podoplanin in

Malignant Progression of Tumor.

Cells 2022, 11, 575. https://doi.org/

10.3390/cells11030575

Academic Editor: Alexander E.

Kalyuzhny

Received: 14 January 2022

Accepted: 5 February 2022

Published: 7 February 2022

Publisher's Note: MDPI stays neutral with regard to jurisdictional claims in published maps and institutional affiliations.

Copyright: (c) 2022 by the authors. Licensee MDPI, Basel, Switzerland. This article is an open access article distributed under the terms and conditions of the Creative Commons Attribution (CC BY) license (https:// creativecommons.org/licenses/by/ $4.0 /)$.
Keywords: podoplanin; PDPN; tumor malignancy; tumor marker; antibody therapy; cancer-specific monoclonal antibody; CasMab

\section{PDPN Structure and Functions}

\subsection{PDPN Structure}

Podoplanin (PDPN)/T1 $\alpha /$ E11 antigen/PA2.26 antigen/Aggrus possesses a heavily glycosylated $\mathrm{N}$-terminal extracellular domain (approximately 130 amino acids), followed by a single transmembrane domain and a short intracellular domain (approximately 10 amino acids) (Figure 1) [1,2]. The N-terminal extracellular domain has a repeat sequence of EDxxVTPG, known as the PLAG1 to PLAG3 domains. PLAG stands for "platelet aggregation-stimulating", which is derived from the platelet aggregation-inducing function of PDPN [3]. Furthermore, several PLAG-like domains (PLDs, one of which is also named the PLAG4 domain) with similar sequences have been identified [4-12]. About half of the molecular weight of PDPN comes from O-type sugar chains. The sugar modifications of the PDPN ectodomain are typical mucin O-glycans with galactose-linked $\beta 1,3$ to $\mathrm{N}$-acetylgalactosamine (GalNAc), called core $1 \mathrm{O}$-glycans $[13,14]$. Using sugar chain-deficient $\mathrm{CHO}$ cell lines, such as Lec1, Lec2, and Lec8, sialic acid is essential for PDPN functions [13]. The O-glycosylation sites at Thr52 in PLAG3 or PLD/PLAG4 have been reported to be crucial for PDPN-induced platelet aggregation $[12,14]$. 


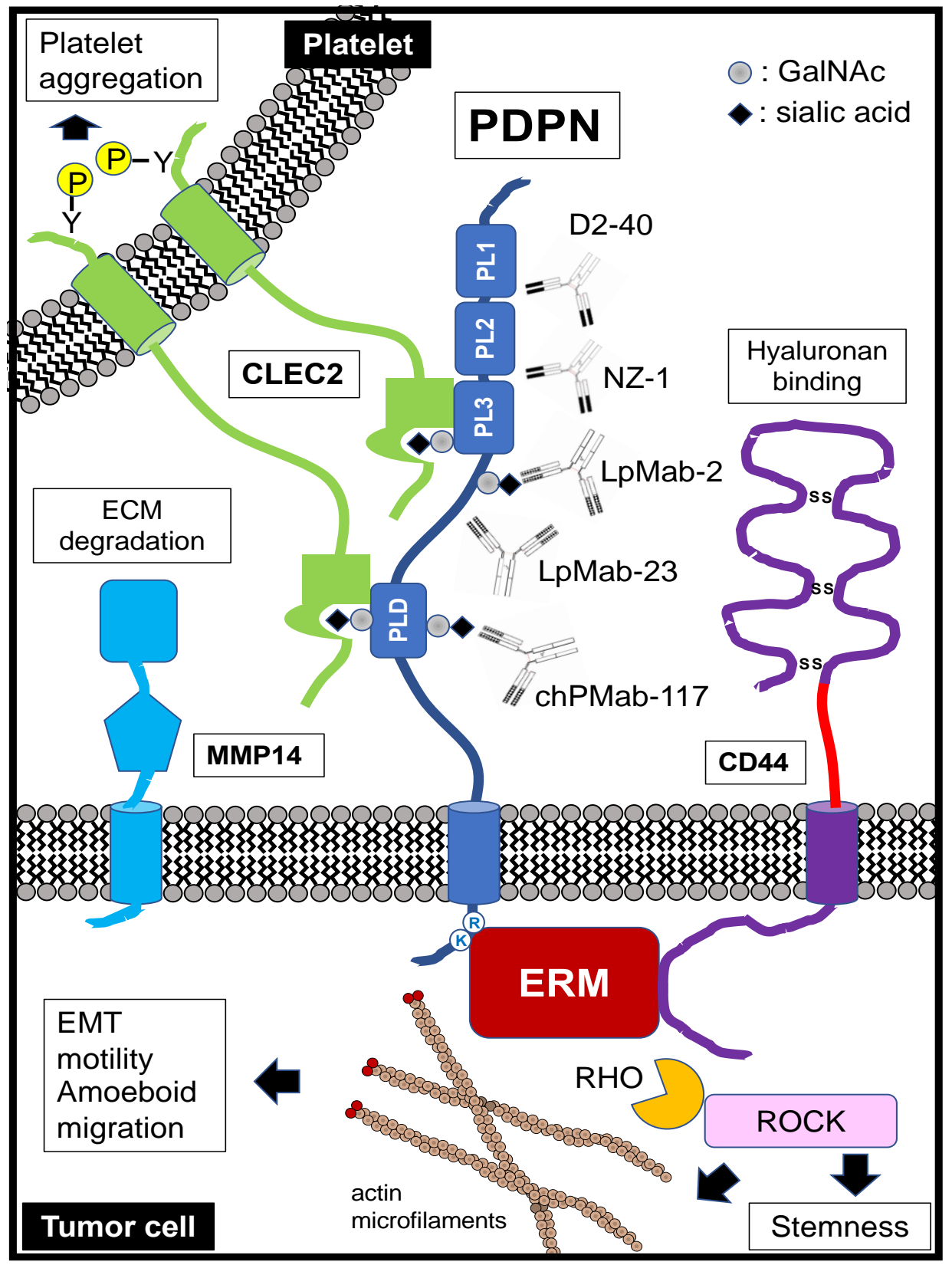

Figure 1. Schematic representation of podoplanin (PDPN) structure and functions. PDPN is a type I transmembrane glycoprotein consisting of an extracellular domain, a transmembrane portion, and a short cytoplasmic tail. The PDPN extracellular domain contains PLAG1-3 (PL1, PL2, and PL3) domains and PLAG-like domain (PLD). C-type lectin-like receptor 2 (CLEC-2), a platelet receptor, recognizes both the sialylated PLAG3 domain and PLD with the adjacent PDPN peptides, inducing CLEC-2 tyrosine phosphorylation and platelet aggregation. The intracellular domain of PDPN contains basic residues (RK), which function as binding sites for ezrin, radixin, and moesin (ERM) family proteins that modulate RHO GTPase activity and promote actin cytoskeleton reorganization to promote cell migration, motility, and EMT. PDPN interacts with hyaluronan receptor CD44 and matrix metalloproteinase 14 (MMP14), promoting hyaluronan-binding and extracellular matrix (ECM) degradation, respectively. Anti-PDPN mAb NZ-1 recognizes the PLAG2/3 domain, exhibits a neutralizing activity for PDPN-CLEC-2 interaction, and inhibits PDPN-induced platelet aggregation and metastasis. Anti-PDPN mAb D2-40 identifies the PLAG1/2 domain and is widely employed for immunohistochemistry. A cancer-specific mAb (CasMab) to PDPN, LpMab-2, recognizes a glycopeptide (Thr55-Leu64) of human PDPN. A CasMab to PDPN, LpMab-23 recognizes a naked peptide of human PDPN (Gly54-Leu64), especially Gly54, Thr55, Ser56, Glu57, Asp58, Arg59, Tyr60, and Leu64 of PDPN, and is a critical epitope of LpMab-23. A CasMab to PDPN, chPMab-117 recognizes the glycopeptide of PDPN (Ile78-Thr85), which includes O-glycosylated Thr85. 


\subsection{Molecular Functions of PDPN Extracellular Domain}

C-type lectin-like receptor 2 (CLEC-2), which is a platelet receptor, binds to PDPN and plays a critical role in PDPN-mediated platelet aggregation and lung metastases [15-17]. CLEC-2 was first discovered as a platelet receptor for snake venom, rhodocytin, known as a platelet aggregation-inducing toxin [18-20]. During platelet aggregation, both PDPN and rhodocytin can activate Src kinase families and the phospholipase $\mathrm{C} \gamma 2$ (PLC $\gamma 2$ ) pathway. These results suggested that PDPN is a CLEC-2 physiological ligand $[15,16]$. Upon PDPN binding to CLEC-2, Syk tyrosine kinase is recruited to the hemi-immunoreceptor tyrosine-based activation motif of CLEC-2. Activated Syk phosphorylates the LAT or SLP-76 adaptor proteins, which activate effector enzymes, PLC $\gamma 2$, resulting in platelet aggregation [18,21-23] (Figure 1).

PDPN possesses well-conserved PLAG domains in the extracellular region [24] (Figure 1). In humans, the PLAG3 domain has an O-glycan at Thr52. Its structure is primarily a disialyl core 1 (NeuAc $\alpha 2-3 \mathrm{Gal} \beta 1-3$ (NeuAc $\alpha 2-6)$ GalNAc $\alpha 1-O-T h r)$ [14]. CLEC-2 was thought to recognize the sialylated PLAG3 domain since sialylation is essential for PDPN-induced platelet aggregation. However, rhodocytin can bind to CLEC-2 and aggregates platelets in the absence of carbohydrates. To elucidate the structural basis of PDPN and rhodocytin in complex with CLEC-2, the crystallographic structures were solved. Both PDPN and rhodocytin employ a two-site interaction mode. The noncanonical face of CLEC-2 is commonly used in both interactions. Other interactions are ligand-specific. Carboxyl groups from the sialic acid residues on PDPN and the C-terminus of the rhodocytin $\alpha$ subunit interact differently at the second binding site of CLEC-2. A similar interaction between PDPN and CLEC-2 was observed at PLD/PLAG4 domain [12].

These results indicate that CLEC-2 recognizes both sialylated O-glycan and the adjacent peptide of PDPN [25] (Figure 1). Furthermore, this recognition mode plays a crucial role in the strategy of tumor-specific targeting therapy (Section 5.3).

\subsection{Molecular Functions of PDPN Intracellular Domain}

PDPN is concentrated in actin-rich microvilli and plasma membrane projections, including filopodia, lamellipodia, and ruffles, where it co-localizes with ezrin, radixin, moesin (ERM) family proteins (Figure 1). Ezrin and moesin, but not radixin, can be coimmunoprecipitated together with PDPN [26]. The intracellular domain of PDPN contains juxtamembrane basic residues (RK) that act as binding sites for ERM family proteins [27]. Upon binding to them, the ezrin family proteins modulate Rho GTPase activity and promote actin cytoskeleton reorganization, which promotes cell migration, invasion, and stemness [28,29]. Interaction with ERM family proteins is essential for PDPN-mediated epithelial-to-mesenchymal transitions (EMTs) in tumor development [1,30,31], as well as lymphangiogenesis and the immune response [30]. Furthermore, two serine residues in the intracellular domain are phosphorylated by protein kinase A and cyclin-dependent kinase 5, which suppresses cell motility [31]. These results suggest that the phosphorylation of the intracellular domain may affect PDPNERM protein interaction and Rho GTPase activation.

\section{Physiological Roles of PDPN}

\subsection{Lungs}

PDPN is identical to T1 $\alpha$, which encodes an antigen expressed at the apical membrane of lung type I alveolar epithelium [32,33]. Lung type I alveolar cells cover more than $95 \%$ of the alveolar surface and are essential for gas-exchange functioning. During lung morphogenesis, the PDPN expression pattern changes from widespread in the embryonic lung epithelium to an expression that is restricted to type I alveolar cells of the distal epithelium [32,34]. Mice lacking Pdpn die shortly after birth due to respiratory defects. The lungs of Pdpn KO mice did not sufficiently fill with air. The distal lung showed marked dense cellularity and abnormal terminal respiratory units, but only a few attenuated type I cells $[35,36]$. These results indicate that PDPN regulates the proliferation and differentiation of lung type I alveolar epithelial cells. 


\subsection{Lymphatic Endothelial Cells}

PDPN expression in the lymphatic endothelium was reported and named as "E11 antigen" [37]. PDPN is one of the most highly expressed lymphatic-specific genes; however, it is not expressed in blood vascular endothelial cells [38]. Therefore, PDPN is employed for pathological diagnosis as a highly specific lymphatic endothelial cell marker. Until the discovery of PDPN, there was no way to distinguish between blood and lymph vessels in pathological diagnosis, and specific antibodies against PDPN greatly improved the accuracy of pathological diagnosis. PROX-1, a lymphatic-specific homeobox protein, regulates PDPN in lymphatic endothelial cells [39].

Pdpn KO mice also exhibited impaired lymphatic transport and lymphedema formation [35]. Furthermore, the PDPN-CLEC-2 interaction is essential for platelet aggregation and embryonic blood lymphatic vascular separation. In embryonic development, lymphatic network formation is initiated from the formation of lymph sacs, which sprout from the cardinal vein. This separation is essential for lymphatic system development [40,41]. Uhrin et al. demonstrated that PDPN-mediated platelet activation is involved in the separation process. Platelet aggregation initiates the separation at the zone of PDPN-expressing lymph sacs and cardinal veins. This phenotype was not observed in Pdpn KO embryos. A similar phenotype is also induced via the treatment of pregnant mice with acetyl salicylic acid, PDPN-blocking antibodies, or through inactivation of the kindlin-3 gene required for platelet aggregation [42]. Furthermore, CLEC-2 KO mice also show a defect in blood lymphatic vessel separation [43]. Therefore, the interaction between endothelial PDPN and circulating platelets is crucial in separating the lymphatic vessels from the blood vascular system.

\subsection{Podocyte}

The term "podoplanin" is derived from its expression in kidney podocytes. Podocytes have foot processes that attach to glomerular capillaries at the glomerular basement membrane and play critical roles as slit diaphragm filtration barriers. This barrier depends on their highly differentiated postmitotic phenotype. PDPN is expressed on the apical surface of podocytes facing the luminal urinary side, and the loss of its expression is associated with foot process flattening and proteinuria, with decreased glomerular permeability in animal models $[44,45]$. These results indicate a crucial function of PDPN in maintaining normal podocyte morphology and glomerular homeostasis. However, the mechanism by which PDPN maintains the specific structure of foot processes remains unknown.

\section{PDPN Overexpression in Cancer as a Diagnostic Marker}

\subsection{PDPN Overexpression in Tumors}

PDPN expression has been reported in many cancers, including squamous cell carcinomas (head and neck, lung, uterine, oral, and esophageal carcinomas), malignant gliomas [46,47], mesotheliomas [48], bladder cancers [49], osteosarcoma [50], ovarian cancer [51], and testicular tumors [52]. Table 1 summarized the clinicopathological significance of PDPN overexpression and its association with poor prognosis. In contrast, PDPN expression in lung squamous cell carcinoma (SCC) is associated with a decreased incidence of lymph node metastases [53] and a better prognosis [54].

PDPN expression is observed not only in tumor cells but also in the tumor stroma, which includes CAFs. Elevated PDPN expression in CAFs from lung [55-57], breast [58], and pancreatic [59] tumors is correlated with tumor malignancy and poor prognosis (Table 1). PDPN-expressing CAFs promote tumor cell resistance to EGFR tyrosine kinase inhibitors [60]. Furthermore, PDPN-positive CAFs express high TGF- $\beta$ [57] and PDPNpositive CAF cases display high CD204 TAMs and low CD8/FOXP3 T cells, which are associated with an immunosuppressive tumor microenvironment [61]. In Section 4.4, we discuss the roles of CAF in tumor stroma in detail. 


\subsection{Pathological Diagnosis by Specific Antibodies}

As shown in Table 1, the monoclonal antibody $(\mathrm{mAb}) \mathrm{D} 2-40$ has been employed for immunohistochemical staining for tumor diagnosis and tumor lymphangiogenesis [62]. D2-40 was originally established against an unidentified M2A protein derived from germ cell tumors [63]. Schacht et al. discovered that D2-40 specifically detects human PDPN [64]. The epitope of D2-40 was determined to be the PLAG1/2 domain [65].

Our groups previously established NZ-1 series (NZ-1, NZ-1.2, NZ-1.3, or NC-08) among anti-PDPN mAbs [16,65-74], which have also been employed for tumor diagnosis by means of immunohistochemistry (Table 1). NZ-1 possesses an exceptionally high affinity to a dodecapeptide (PA tag) with characteristically slow dissociation kinetics [75]. The crystal structure of the PA tag-NZ-1 complex revealed that NZ-1 recognizes a central segment of the PA tag peptide in a tight $\beta$-turn configuration [76], allowing the insertion of a PA tag into a loop structure. The PA tag system is widely used in protein detection and purification. Furthermore, the NZ-1-PA tag system efficiently promotes the crystallization of the target protein [77], implying that the NZ-1-PA tag system can be used as a crystallization chaperone to solve the target protein structure.

Moreover, NZ-1 series mAbs are used to collect circulating tumor cells (CTCs), which are useful indicators of micro-metastasis. However, the detection of rare tumor cells, contaminated in a vast majority of normal hematological cells, remains to be technically improved [78,79]. To detect CTCs effectively, a novel microfluidic system (CTC-chip) was developed using NZ-1 mAbs. Among them, an anti-PDPN antibody (clone NZ1.2) effectively captured PDPN-high CTCs in peripheral blood from 15 of 22 malignant pleural mesothelioma (MPM) patients [72]. However, there is a limitation in that the above system can capture PDPN-high CTCs, but not PDPN-low CTCs from non-epithelioid MPM (low PDPN expression). To overcome this limitation, a novel CTC-detection chip was developed by combining the PDPN antibody with an anti-EGFR antibody (cetuximab). The cell-capture efficiency of the Cocktail-chip was improved and reached $100 \%$ in all histological MPM cell lines. Furthermore, the CTC counts were significantly associated with the clinical stage of non-epithelioid MPM [80]. These results provide a novel strategy for MPM diagnosis and could offer useful information for treating and predicting MPM patients' prognoses.

Table 1. Association of PDPN expression with poor clinical outcomes.

\begin{tabular}{|c|c|c|c|c|c|}
\hline Organ & $\begin{array}{l}\text { Tumor } \\
\text { Type }\end{array}$ & $\begin{array}{c}\text { PDPN } \\
\text { Expression }\end{array}$ & Functional and/or Clinical Significance & Detection (mAb) & Ref \\
\hline \multirow[t]{3}{*}{ Esophageal } & $\mathrm{SCC}^{1}$ & Tumor & $\begin{array}{l}\text { PDPN membrane expression is correlated with } \\
\text { vimentin cytoplasmic expression. }\end{array}$ & $\mathrm{IHC}^{12}(\mathrm{D} 2-40)$ & [81] \\
\hline & SCC & Tumor & $\begin{array}{l}\text { PDPN knockdown suppresses tumor } \\
\text { formation in mice and enhances } \\
\text { chemosensitivity. }\end{array}$ & IHC (D2-40) & [82] \\
\hline & SCC & Tumor & $\begin{array}{l}\text { PDPN is involved in collective cell invasion in } \\
\text { the absence of EMT }{ }^{7} \text {. }\end{array}$ & IHC (D2-40) & [83] \\
\hline \multirow[t]{2}{*}{ Oral } & SCC & Tumor & $\begin{array}{l}\text { PDPN expression correlates with cervical } \\
\text { lymph node metastases and clinical outcome. }\end{array}$ & IHC (D2-40) & [84] \\
\hline & SCC & Tumor & $\begin{array}{l}\text { High PDPN expression in the biopsy specimen } \\
\text { predicts poor response to neoadjuvant } \\
\text { radiochemotherapy with carboplatin. }\end{array}$ & IHC (D2-40) & [85] \\
\hline Skin & SCC & Tumor & $\begin{array}{l}\text { High PDPN expression in the primary tumor } \\
\text { predicts poor clinical outcomes. }\end{array}$ & IHC (D2-40) & [86] \\
\hline Head \& neck & SCC & Tumor & $\begin{array}{l}\text { PDPN knockdown suppresses tumor } \\
\text { migration and invasion. }\end{array}$ & $\mathrm{IHC}\left(\mathrm{NR}^{14}\right)$ & [87] \\
\hline Kidney & $\operatorname{ccRCC}^{2}$ & Tumor & $\begin{array}{l}\text { High PDPN expression was an independent } \\
\text { adverse prognostic factor for patient survival. }\end{array}$ & IHC (18H5) & [88] \\
\hline
\end{tabular}


Table 1. Cont.

\begin{tabular}{|c|c|c|c|c|c|}
\hline Organ & $\begin{array}{l}\text { Tumor } \\
\text { Type }\end{array}$ & $\begin{array}{c}\text { PDPN } \\
\text { Expression }\end{array}$ & Functional and/or Clinical Significance & Detection (mAb) & Ref \\
\hline Brain & $\mathrm{GBM}^{3}$ & Tumor & $\begin{array}{l}\text { PDPN is expressed in the mesenchymal type of } \\
\text { GBM, which presents the worst prognosis. }\end{array}$ & IHC (NZ-1.2) & [89] \\
\hline Breast & $\mathrm{AC}^{4}$ & $\mathrm{CAF}^{6}$ & $\begin{array}{l}\text { Tumors with a negative ER }{ }^{8} \text { status yielded the } \\
\text { highest number of PDPN-expressing CAFs. }\end{array}$ & IHC (D2-40) & [58] \\
\hline \multirow[t]{4}{*}{ Lung } & SCC & CAF & $\begin{array}{c}\text { PDPN-positive CAFs express high TGF- } \beta \text { and } \\
\text { are associated with the immunosuppressive } \\
\text { TME }^{9} \text {. }\end{array}$ & TCGA $^{13}$ microarray & [57] \\
\hline & $\mathrm{AC}$ & CAF & $\begin{array}{l}\text { PDPN-positive vascular adventitial fibroblasts } \\
\text { enhance tumor formation in mice. }\end{array}$ & IHC (D2-40) & [55] \\
\hline & $\mathrm{AC}$ & CAF & $\begin{array}{l}\text { PDPN-positive CAFs cases display high } \\
\text { CD204 TAMs }{ }^{10} \text { and low CD8/FOXP3 T cells, } \\
\text { associated with the immunosuppressive TME. }\end{array}$ & TCGA microarray & [61] \\
\hline & $\mathrm{AC}$ & CAF & $\begin{array}{l}\text { PDPN-positive CAFs promote tumor cell } \\
\text { resistance to EGFR TKIs }{ }^{11} \text {. }\end{array}$ & IHC (D2-40) & [60] \\
\hline Pancreas & $\mathrm{AC}$ & CAF & $\begin{array}{l}\text { PDPN-positive CAFs enhance the invasion of } \\
\text { cancer cells more effectively than } \\
\text { PDPN-negative CAFs. }\end{array}$ & IHC (D2-40) & [59] \\
\hline Esophageal & $\mathrm{AC}$ & CAF & $\begin{array}{l}\text { PDPN-expressing CAFs were observed in } \\
\text { invasive AC, but not in precursor lesions. }\end{array}$ & IHC (D2-40) & [90] \\
\hline Bile duct & $\mathrm{CCA}^{5}$ & CAF & $\begin{array}{l}\text { Association between lymphatic vessel density } \\
\text { and PDPN expression in CAFs. PDPN } \\
\text { promotes the migratory ability of CAFs. }\end{array}$ & IHC (sc-134482) & [91] \\
\hline
\end{tabular}

${ }^{1}$ SCC, squamous cell carcinoma; ${ }^{2}$ ccRCC, clear cell renal cell carcinoma; ${ }^{3}$ GBM, glioblastoma; ${ }^{4}$ AC, adenocarcinoma; ${ }^{5} \mathrm{CCA}$, cholangiocarcinoma; ${ }^{6} \mathrm{CAF}$, cancer-associated fibroblast; ${ }^{7} \mathrm{EMT}$, epithelial-to-mesenchymal transition; ${ }^{8} \mathrm{ER}$, estrogen receptor; ${ }^{9} \mathrm{TME}$, tumor microenvironment; ${ }^{10} \mathrm{TAM}$, tumor-associated macrophage; ${ }^{11}$ TKI, tyrosine kinase inhibitor; ${ }^{12}$ IHC, immunohistochemistry; ${ }^{13}$ TCGA, The Cancer Genome Atlas; ${ }^{14}$ NR, not reported.

\subsection{The Mechanism of PDPN Overexpression in Tumors}

In lymphatic endothelial cells, the transcriptional factor PROX-1 is a master regulator of PDPN transcription [39]. However, during the malignant progression of tumors, PDPN transcription has been reported to be regulated by multiple cytokines and transcriptional factors.

Hantusch et al. first reported on PDPN promoter analysis. They investigated about $2 \mathrm{~kb}$ of a 5'-flanking region of the PDPN gene and revealed a GC-rich region a d multiple Sp1, AP-4, and NF-1 sites. They characterized the molecular mechanism controlling basal PDPN transcription in human osteoblast-like MG63 (PDPN high) versus Saos-2 cells (PDPN low). An in vitro DNase I footprinting assay revealed multiple DnaseI-protected regions within the region bp -728 to -39 , present in MG63 but not Saos- 2 cells. Among these regions, two Sp1/Sp3 binding sites were identified as potential regions for PDPN transcriptional regulation. Overexpression of Sp1 and Sp3 independently increased promoter activity and PDPN transcription in Saos-2 cells. Chromatin immunoprecipitation (ChIP) analysis confirmed Sp1/Sp3 recruitment on the PDPN promoter. These results indicate that Sp1/Sp3 members constitutively bind to their binding sites of the PDPN promoter and stimulate transcription. Furthermore, they suggest the existence of additional transcription factor complexes at the upstream regions on the PDPN promoter [92].

The oncogenic transcription factor activator protein AP-1, composed of JUN and FOS, is essential for neoplastic transformation and malignant progression in skin carcinogenesis. Durchdewald et al. employed a mouse skin carcinogenesis model, K5-SOS-F transgenic mice $\left(\mathrm{Fos}^{\mathrm{f} / \mathrm{f}} \mathrm{SOS}^{+}\right.$), and demonstrated that Pdpn is a FOS target gene. In the mouse model, FOS-dependent PDPN expression was observed in mouse skin tumors induced by 12-O-tetradecanoylphorbol-13-acetate (TPA). Pdpn promoter activity was impaired in Fos $\mathrm{KO}$ mouse embryonic fibroblasts, which could be restored by ectopic Fos expression. Furthermore, the direct binding of FOS at the TPA-responsive element-like motif of Pdpn promoter was revealed through ChIP analysis. These results indicate the significance of the FOS-PDPN axis in neoplastic transformation and/or the malignant progression of 
skin tumors [93]. The involvement of AP-1 was also reported in the MG63 cell model, as described above [94]. Furthermore, SRC oncoprotein, an upstream regulator of FOS, utilized CAS to induce PDPN expression [95].

In primary human glioblastoma (GBM) and glioma cell lines, an inverse correlation between PDPN expression and PTEN levels was reported. Elevated PDPN was also observed in the subventricular zone of the brain in PTEN-deficient mice. These results indicate the involvement of PI3-kinase in PDPN expression. In human glioma cells lacking PTEN, reintroduction of wild-type PTEN, inhibition of PI3-kinase by LY294002, or inhibition of AP-1 activity by dominant-negative JUN and FOS resulted in potent downregulation of PDPN expression. These results indicated that the increased PDPN expression in human GBM is mediated by the loss of PTEN function and PI3K-AKT-AP-1 signaling pathway activation [96].

PDPN is involved in the tumorigenesis of oral SCC. Mei et al. demonstrated that the ErbB3-binding protein-1 (EBP1) can function as a transcriptional factor for promoting PDPN transcription during malignant progression. ChIP analysis revealed that EBP1 binds to the PDPN promoter surrounding the Sp1/Sp3 site. EBP1 overexpression promoted PDPN transcription and invasiveness. In contrast, EBP1 knockdown inhibited PDPN transcription, invasiveness, and tumor formation in immunodeficient mice. Therefore, EBP1 plays a key role in the upregulation of PDPN and contributes to oral tumorigenesis [97].

PDPN regulators were also reported through a pathological approach. In the pathological tumor section, PDPN-expressing tumor cells have been observed sometimes at the invasive front, where CD45-positive inflammatory cells infiltrate. Laser capture microscopy combined with gene expression profiling revealed that interferon-responsive gene expression is upregulated in PDPN-positive cells at the invasive front. Indeed, PDPN expression can be induced by interferon- $\gamma$ (IFN- $\gamma$ ), transforming growth factor- $\beta$ (TGF- $\beta$ ), and/or tumor necrosis factor- $\alpha$ (TNF- $\alpha$ ) treatment in SCC cell lines. Furthermore, STAT1 knockdown (a signaling component of IFN- $\gamma$ ) in SCC cells suppressed tumor cell invasion in the subcutaneous tumor transplantation model [98]. The involvement of the TGF- $\beta$ SMAD pathway in PDPN expression has been reported in oral/pharyngeal SCCs [99] and fibrosarcoma cells [100]. TGF- $\beta$-induced PDPN expression was inhibited by SMAD4 knockdown or TGF- $\beta$ type I receptor kinase inhibitor treatment. These results highlight the significance of inflammatory cytokines produced by inflammatory cells, stimulating PDPN expression at the invasive front of the tumor.

\section{Roles of PDPN in Invasion-Metastatic Cascade}

Tumor metastasis is a multistep biological process termed the invasion-metastasis cascade [101], which includes (1) cancer cell dissemination from primary sites, (2) the acquisition of migration/invasion phenotype, (3) intra/extravasation, (4) survival in circulation, and (5) adaptation and colonization in a distant organ. Furthermore, (6) the nonneoplastic stromal cells, including CAFs and tumor-infiltrating lymphocytes (TILs), also mediate these events, and these cells are termed the tumor microenvironment (TME). Recent advances provide insights into the relevance of PDPN in the multiple steps of the invasion-metastasis cascade (Figure 2).

\subsection{Migration and Invasion}

EMT is a cellular process in which epithelial cells acquire mesenchymal phenotypes (fibroblast-like morphology and cytoarchitecture, increased migratory capacity) and lose epithelial features (stable cell-cell junctions, apical-basal polarity, and interactions with basement membrane). In TME, EMT is triggered by various cytokines produced not only by tumor cells but also by stromal and immune cells. During EMT, changes occur in gene expression, including EMT transcriptional factors (EMT-TFs) and their targets, as well as epigenetic regulation, resulting in the suppression of these epithelial characteristics and the acquisition of mesenchymal characteristics [102,103]. PDPN has been referred to as "PA2.26 antigen," and its forced expression promotes cell scattering, migration, and EMT- 
like morphological changes with the loss of epithelial markers (E-cadherin and keratin) and the upregulation of mesenchymal markers (N-cadherin and Vimentin) $[26,95,96]$. PDPN's cytoplasmic tail binds to ezrin and/or moesin, which are members of the ERM protein family of membrane-cytoskeleton linkers and are required for RhoA activation and EMT induction $[27,104]$.

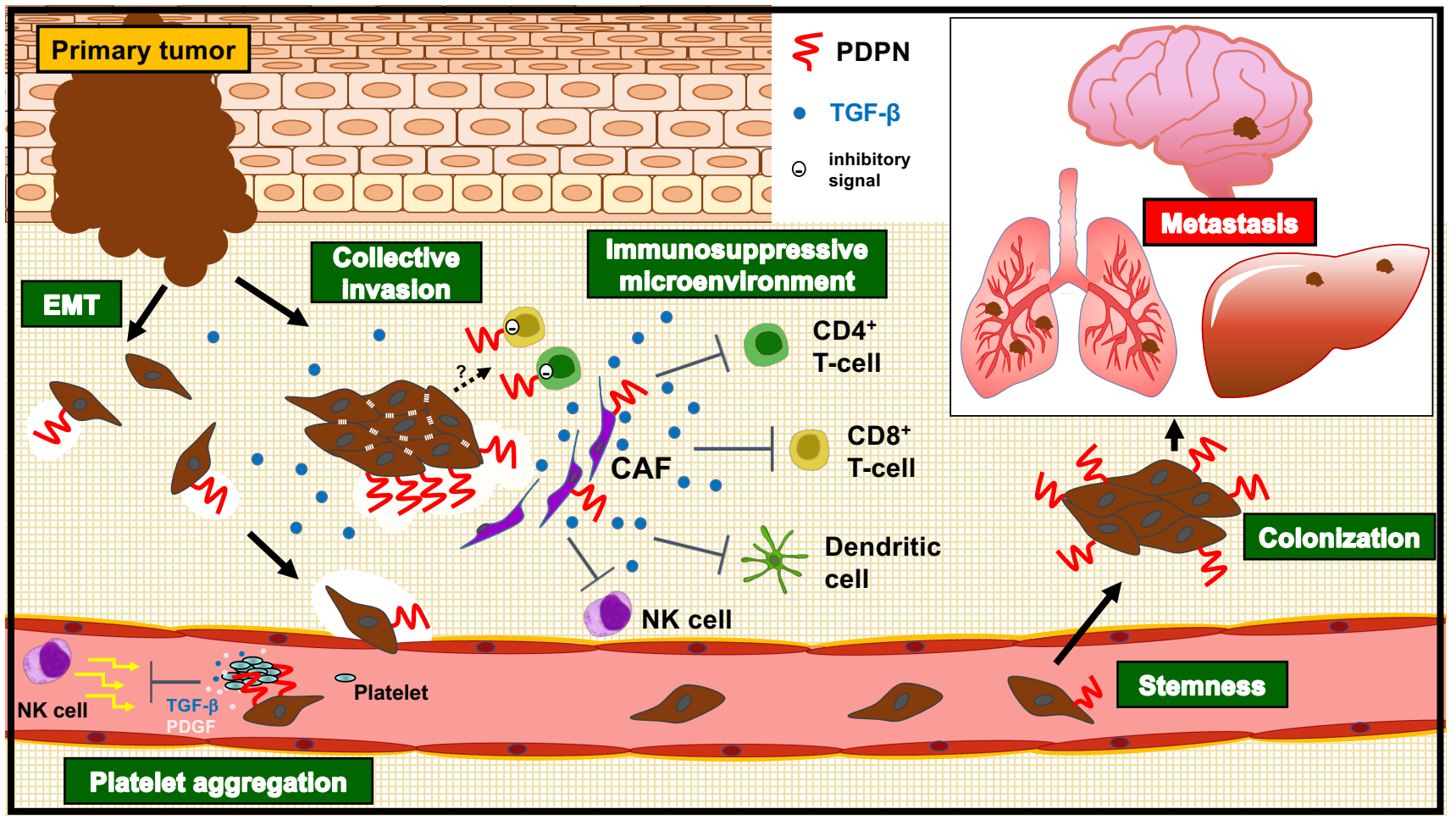

Figure 2. Roles of PDPN in the tumor-metastatic cascade. Tumor metastasis is a multistep biological process termed the invasion-metastasis cascade. PDPN-mediated induction of epithelial to mesenchymal transition (EMT) reduces E-cadherin levels and promotes the dissemination of cancer cells from primary sites. PDPN recruits CD44 and MMP14 at filopodia, lamellipodia, and invadopodia and stimulates hyaluronan-binding and extracellular matrix (ECM) degradation, respectively. The intracellular actin cytoskeleton reorganization by PDPN also promotes cell motility. These events confer the migration/invasion phenotype and stimulate the intravasation. Note that PDPN expression is observed at the invasive front of the tumor's collective invasion, which implies the importance of tumor-stroma interaction. PDPN-mediated platelet aggregation promotes survival of shear stress and immune attacks in the circulation. Furthermore, platelet-derived factors (PDGFs and TGF- $\beta$ ) also promote the tumor cell survival and plasticity. PDPN confers stemness, probably through the Rho-ROCK pathway, and promotes colonization in a distant organ. Furthermore, PDPN-positive CAFs construct the immunosuppressive TME by producing TGF- $\beta$, a potent immunosuppressive cytokine. Furthermore, PDPN is expressed in both $\mathrm{CD}^{+}$and $\mathrm{CD} 8^{+} \mathrm{T}$ cells and acts as a co-inhibitory receptor, which could control tumor immunity. Thus, PDPN is involved in multiple steps of the invasion-metastasis cascade.

PDPN is reported to interact with various migration- and invasion-promoting membrane proteins, including the hyaluronan receptor CD44 and matrix metalloproteinase 14 (MMP14, also known as MT1-MMP) (Figure 1). In a mouse skin carcinogenesis model, PDPN interacts with the standard isoform of CD44 (CD44s) during the progression to highly aggressive SCCs. CD44 is a highly glycosylated type I transmembrane glycoprotein that contains a significant number of variant isoforms (CD44v) due to alternative splicing. CD44 also binds to ERM proteins through its cytoplasmic tails [105]. PDPN and CD44 colocalize at cell-surface protrusions. PDPN-induced migration requires CD44 in MDCK 
cells, and knockdown of CD44 and PDPN in oral SCC cells affect cell spreading [106]. These results indicated that PDPN directly interacts with CD44 and modulates cell migration.

To invade the surrounding tissue, cancer cells must destroy and remodel the extracellular matrix (ECM), including both the basement membrane and the stromal ECM. PDPN was reported to stimulate MMP14 expression with oral SCC cell invasion by the activation of the small GTPase Cdc42 [107]. PDPN makes a complex with MMP14 and co-localizes at cell-surface protrusions, suggesting the potential of ECM destruction at sites [107]. In tumor cell invasion, not only tumor cells but also stromal cells express and secrete MMPs, which contributes to the destruction of the ECM for tumor invasion [108] (Figure 2). Furthermore, PDPN can stimulate TGF- $\beta$ secretion in oral SCC cells, which activates surrounding fibroblasts, upregulating MMP2 and MMP14 expression [109]. We discuss the roles of PDPN in CAFs and TGF- $\beta$ below (Section 4.4).

The recruitment of the glycoprotein by specialized cell-surface protrusions, called invadopodia, which recruit glycoproteins, is implicated in tumor cell invasion [110,111]. PDPN functions as a component of invadopodia in breast cancer and SCC cells $[112,113]$. The recruitment of PDPN to the adhesion ring of invadopodia requires binding to ERM proteins and association with lipid rafts. PDPN promotes invadopodia maturation and stabilization by activating the RhoC-Rho kinase (ROCK)-LIM kinase-cofilin signaling pathway, which stimulates the degradation of the ECM [112]. CD44 was also found to be a component of invadopodia, where it appears to interact with PDPN and recruit MMP14 $[114,115]$. However, the role of the PDPN-CD44 interaction in invadopodia assembly and maturation should be investigated in detail.

The diversity of motility mechanisms has been recognized in recent years. The most commonly observed type of motility in histological sections is the migration of groups of cells [116]. Analyses of the clusters indicate that the cells retain cell-cell adhesion and that there is communication from the leading edge and the trailing cells within each cluster [117,118]. Wicki et al. employed a transgenic mouse model of carcinogenesis and biopsies from cancer patients to investigate the functional contribution of PDPN to collective migration. Via the transgenic expression of PDPN in Rip1Tag2 transgenic mice (expression of simian virus 40 large and small $\mathrm{T}$ antigens under the control of insulin promoters; mouse model of pancreatic $\beta$ cell carcinogenesis), PDPN caused an acceleration of tumor progression with a higher incidence of tumor invasion and tumor malignancy, without the formation of lymph-node or distant-organ metastasis. PDPN induces collective cell migration through filopodia formation via the downregulation of the activities of RhoA, Cdc42, and Rac in the absence of EMT. In an immunohistochemical analysis for PDPN and E-cadherin in the collective invading front of human tumors, PDPN is detectable exclusively in the outer cell layer of the invading front, whereas E-cadherin is expressed in all carcinoma cells [119].

Ameboid migration is characterized by a rounded cell morphology and the continuous formation of protruding membrane blebs, allowing the cell to squeeze through the ECM [120] and reducing the requirement for ECM proteolytic degradation [121]. In fact, MMP inhibitors are ineffective at inhibiting ameboid invasion [122]. RhoA, ROCK, and Myosin II signaling drive the rapid and high actomyosin contractility, which mediates the ameboid characteristics. PDPN is reported to enhance ameboid invasion in melanoma. PDPN expression in murine melanoma cells drives the rounded cell morphology, increasing motility and invasion. PDPN induces the phosphorylation of ERM proteins and drives cell blebbing and protrusions. These events are inhibited by ROCK inhibitor (GSK269962A). PDPN expression promotes the dedifferentiation of melanoma cells, and the loss of PDPN restores pigmentation and melanocyte differentiation. These findings support the role of PDPN as a functional biomarker for dedifferentiated and ameboid invasive melanoma, and as a promising therapeutic target [123]. 


\subsection{Platelet Aggregation}

PDPN was named "Aggrus," which promotes platelet aggregation $[3,13]$. Tumor cell-induced platelet aggregation is thought to be significant for hematogenous metastasis. The intravasated tumor cells receive shear stress from blood flow and attacks from immune cells [124]. To overcome and survive in the circulation, PDPN induces platelet aggregation by binding to CLEC- 2 on platelets, which promotes embolization and the evasion of immune cells $[125,126]$ (Figure 2). Activated platelets also release factors, including PDGFs and TGF- $\beta$. PDGFs activate cell proliferation and survival signaling via the Ras-ERK and PI3K-AKT pathways, respectively [101]. TGF- $\beta$ is a multifunctional protein, which promotes tumor cell migration/invasion and plasticity through EMT program activation [127]. These factors help tumor cells extravasate and proliferate at metastatic sites.

\subsection{Stemness (Colonization)}

Adult stem cells possess the ability to self-renew and produce differentiated progeny cells, which contribute to tissue regeneration. In the development of tumors, a small subset of tumor cells, called cancer stem cells (CSCs), are responsible for tumorigenesis, and confer resistance to treatments. These abilities are also important for metastatic colonization and tumor relapse post-treatment. Furthermore, EMT programs can promote stemness, which generates CSCs in many epithelial tissues [128]. PDPN has also been reported to be expressed in cells with tumor-initiating potential.

The PDPN-positive population exhibited clonal expansion ability and tumor formation in mice-characteristics of CSCs, which were initially observed in A431 SCC cells. Individual PDPN-expressing cells created large colonies more often than single cells, which did not express PDPN. Furthermore, PDPN-positive cells showed a higher tumor-initiating potential than PDPN-negative cells [129] (Figure 2). There is no significant difference in the cell cycle between PDPN-positive and negative cells; however, cell death was significantly lower in PDPN-positive cells. The knockdown of PDPN enhanced the cell death of PDPN-positive cells and prevented the formation of large colonies. Moreover, a ROCK inhibitor (Y-27632) suppressed the large colony formation of PDPN-positive cells, but not that of PDPN-negative cells [130]. Since PDPN possesses an ERM-binding domain and can activate the Rho-ROCK pathway, PDPN-mediated ROCK activation is thought to be important for the maintenance of CSC ability. Furthermore, in a collagen gel invasion assay, PDPN-positive A431 cells exhibited higher invasion activity in the presence of fibroblasts, suggesting that cancer stem cell functions of PDPN-positive A431 cells might be supported by the fibrogenic tumor microenvironment [131].

A hierarchical distribution of PDPN with other CSC markers, including CD44 and P63, was revealed in the pathological approach. In the immunohistochemical staining of lung SCC tissue, PDPN is mainly localized at the periphery of invading tumor nests with CD44 and P63. The distribution of the PDPN-positive cell region was more localized to the peripheral area of the tumor nests than that of CD44- and P63-positive cell regions. However, patients who had PDPN-positive tumors with a hierarchical pattern resulted in significantly better overall survival than those with PDPN-negative tumors [54]. Therefore, the roles of PDPN/CD44/P63-positive cells in tumorigenesis remain unclear.

\subsection{Stromal Expression of PDPN and Its Roles in Tumors}

The TME consists of the ECM, cytokines, and a large population of stromal cells, including CAFs, immune cells, endothelial cells, and adipocytes. Tumor stromal cells play crucial roles in constructing the TME, including its capacity to produce ECM, activate $\mathrm{CAFs}$, suppress the immune system, and promote angiogenesis. Furthermore, tumor stromal cells are also the primary sources of inflammatory cytokines, including TGF- $\beta$, IFN- $\gamma$, and TNF- $\alpha$, which are also known as PDPN inducers. Reciprocally, the TME exerts profound effects on tumor growth and progression. As shown in Table 1, PDPN-positive CAFs exhibited poor prognosis in lung SCC [57], as well as lung [55,132-135], breast [58], and pancreas adenocarcinomas [59]. In lung tumor cases, PDPN-positive CAFs promote 
tumor cell malignancy. The subcutaneous co-injection of human lung adenocarcinoma A549 cells with PDPN-positive vascular adventitial fibroblasts resulted in a high rate of tumor formation, lymph node metastasis, and lung metastasis compared with PDPNnegative fibroblasts [55]. Moreover, PDPN-positive CAFs are closely associated with the immunosuppressive tumor microenvironment. PDPN-positive CAF cases display high CD204 ${ }^{+}$tumor-associated macrophage (TAM) levels and a low CD8/FOXP3 T cell ratio [61]. TAMs, mainly M2 TAMs, promote the malignant progression of tumors by producing cytokines involved in angiogenesis, tumorigenesis, matrix remodeling, and immunosuppression [136]. A growing number of studies have shown that FOXP3-positive regulatory $\mathrm{T}$ (Treg) cells in TME secrete immunosuppressive cytokines, including IL-10 and TGF- $\beta$, and inhibit CD8-positive cytotoxic T cells, allowing tumor cells to escape the host's immune surveillance in several cancers [137]. Furthermore, the gene expression profiles of immunosuppressive cytokines were compared using The Cancer Genome Atlas microarray lung SCC data between a PDPN-high group and a PDPN-low group. The PDPN-high group exhibited significantly higher expression of TGF- $\beta 1$, interleukins (IL- $1 \mathrm{~A}, \mathrm{IL}-1 \mathrm{~B}, \mathrm{IL}-$ 6, IL-10), chemokines (CCL2), and growth factors (PDGF-A and B, FGF2) than those in the PDPN-low group. Among them, TGF- $\beta 1$ expression was higher in patient-derived PDPN-positive CAFs. Immunohistochemical analyses revealed that more PDPN-positive CAFs showed higher expression of TGF- $\beta 1$, which was associated with CD204 ${ }^{+}$TAM infiltration in lung SCC. TGF- $\beta$ can inhibit the activation and proliferation of effector T cell subsets, including $\mathrm{T}_{\mathrm{H}} 1, \mathrm{~T}_{\mathrm{H}} 2$ cells, and cytotoxic T lymphocytes. In contrast, TGF- $\beta$ promotes differentiation into Treg cells from naïve $\mathrm{CD}^{+} \mathrm{T}$ cells [138]. These results indicate that PDPN-positive CAFs were associated with the immunosuppressive TME, probably due to TGF- $\beta$ activation (Figure 2). However, it should be investigated whether PDPN triggers the TGF- $\beta$-mediated construction of the immunosuppressive TME. Since TGF- $\beta$ crucially suppresses the immune system, TGF- $\beta$ inhibitors are currently on clinical trials in advanced solid tumors combined with immune checkpoint inhibitors [139]. There is a possibility that PDPN-positive CAFs will become one of the key biomarkers for determining the immunosuppressive TME mediated by TGF- $\beta$.

\subsection{Roles of PDPN in T Cell Immunity}

The expression of co-inhibitory receptors, such as CTLA-4 and PD-1, on effector T cells play a key role in tumor immunity. Chihara et al. functionally validated PDPN as a coinhibitory receptor expressed in both $\mathrm{CD}^{+}$and $\mathrm{CD}^{+} \mathrm{T}$ cells. PDPN participates in a larger co-inhibitory gene program that is driven by the immunoregulatory cytokine IL-27. In T cell-specific Pdpn conditional knockout mice, a significant delay in B16F10 tumor growth was observed. PDPN-deficient CD8 ${ }^{+}$TILs exhibited enhanced TNF production but no significant difference in IL-2, IFN- $\gamma$, or IL-10. The frequency of T cells with a severely exhausted phenotype was also decreased in $P d p n$ cKO mice. These results suggest that PDPN limits the survival of CD8 ${ }^{+}$TILs in the TME. They also identified a transcriptional factor, c-MAF, as a cooperative regulator of PDPN. This molecular circuit provides the basis of co-inhibitory receptors and their transcriptional regulation in $\mathrm{T}$ cells, suggesting the potential to control tumor immunity [140].

Peters et al. reported the roles of PDPN in $\mathrm{CD}^{+} \mathrm{T}$ cells. They observed that PDPN expressed effector $\mathrm{T}$ cells, infiltrating target tissues during autoimmune inflammation. Furthermore, mice harboring a T cell-specific deletion of Pdpn developed exacerbated spontaneous autoimmune encephalomyelitis with increased accumulation of effector CD4 ${ }^{+}$ $\mathrm{T}$ cells in the central nervous system (CNS). In contrast, T cell-specific overexpression of PDPN exhibited defects in T cell expansion and survival. As a result, the mice exhibited the rapid remission of CNS inflammation, indicated by a reduced effector $\mathrm{CD}^{+}{ }^{+} \mathrm{T}$ cell number in the CNS. These results also suggest that PDPN functions as an inhibitory molecule on $\mathrm{T}$ cells by promoting tissue tolerance and limiting the survival and maintenance of $\mathrm{CD}^{+}$ effector T cells in target organs [141]. 
These findings strongly suggest the involvement of PDPN in immune suppression (Figure 2). However, many challenging but exciting questions remain unanswered. For example, what promotes PDPN expression in T cells? What kind of ligand(s) on tumor cells transduce the inhibitory signal to T cells? Furthermore, co-inhibitory receptors, such as immune checkpoint inhibitors, possess immunoreceptor tyrosine-based inhibitory motifs in the cytoplasmic domains [142,143]. However, PDPN does not. Recently, the neutrophil CD177 was identified as a novel PDPN receptor. Both CD177 and CLEC2 similarly changed the PDPN-expressing CAF phosphoproteome and affected PDPNmediated contractility [144]. Further investigations are required to elucidate the mechanism of how PDPN transduces the inhibitory signals in T cells. This is of interest, in relation to the application of this knowledge to cancer immune therapy.

\section{Therapeutic Strategies to PDPN-Overexpressing Tumors}

\subsection{Anti-PDPN Monoclonal Antibodies (mAbs)}

MAbs that target solid tumor antigens have been extensively investigated [145]. Among the FDA-approved mAbs, most mAbs receiving approval for solid tumors have targeted two members of the ERBB family, EGFR or HER2 [146-148]. Additionally, cytotoxic agents with conjugated mAbs against HER2 [146-148], Nectin-4 [149], and TROP2 [150,151] have been approved for solid tumors. A growing number of pre-clinical investigations have been reported because PDPN could be a useful diagnostic marker and an attractive molecular target for cancer therapy. Anti-PDPN mAbs have been developed and showed an antitumor effect with different mechanisms of action.

Anti-human PDPN mAb NZ-1, which recognizes the PLAG2/3 domain, has a neutralizing activity in relation to the PDPN-CLEC-2 interaction and inhibits PDPN-induced platelet aggregation and hematogenous lung metastasis [16,66] (Figure 1). Other anti-PDPN mAbs, P2-0 [152] and MS-1 [153] also recognize the PLAG2/3 domain, and 2F7 [154] recognizes the PLD/PLAG4 domain. These mAbs also suppress platelet aggregation and hematogenous pulmonary metastasis by inhibiting CLEC-2 interaction.

Non-conjugated mAbs exhibit several different mechanisms of action, including antibody-dependent cellular cytotoxicity (ADCC) and complement-dependent cytotoxicity (CDC) activities. NZ-8 is a rat-human chimeric antibody derived from NZ-1, and its ADCC and CDC activities against MPM were evaluated in vitro and in an in vivo subcutaneous tumor xenograft model [48]. NZ-8 preferentially recognized PDPN-expressing MPM but not in normal tissues. NZ-8 exhibited higher ADCC activity in the presence of human NK cells and CDC activity compared with NZ-1. Treatment with NZ-8 and human NK cells significantly inhibited tumor growth. Furthermore, chLpMab-7, a mouse-human chimeric anti-PDPN mAb with a different epitope than NZ-1, could not inhibit PDPN-CLEC-2 interaction but suppressed tumor growth and hematogenous metastasis to the lung in a neutralization-independent manner [155]. These findings suggest that ADCC and CDC activities are crucial in targeting therapeutic mAbs to PDPN-expressing tumors.

Drug-conjugated $\mathrm{mAbs}$ rely on direct cytotoxicity of their payloads through receptorbound mAb-drug-conjugate endocytosis [156,157]. PMab-38, an anti-dog PDPN (dPDPN) $\mathrm{mAb}$, reacts with dPDPN-expressing canine melanomas and SCCs [158-160]. A mousecanine chimeric mAb (P38B) conjugated with emtansine as the payload (P38B-DM1) has been challenged for tumor therapy. P38B-DM1 showed cytotoxicity to dPDPN-expressing cells and exhibited higher antitumor activity than P38B in the xenograft model [161]. Recently, anti-PD-1 and anti-PD-L1 mAbs are used in canine tumor treatment [162-164]; the combination of immune checkpoint inhibitors with other antibody drugs is expected to be more effective. Anti-dPDPN mAbs may contribute to the development of canine cancer treatment, which can provide feedback for human cancer treatment. Moreover, our group has developed anti-PDPN mAbs against 18 species of animals [4,6,69,158,165-179]. These mAbs will contribute not only to the research on each animal but also to diagnosis and drug development. We will add novel anti-PDPN mAbs against golden hamsters and ferrets, which are small animal models of severe acute respiratory syndrome coronavirus 
2 infections. Since PDPN is expressed in lung type I alveolar epithelium, these mAbs will contribute to the evaluation of the pathogenesis of virus-infected lung type I alveolar epithelial cells.

PDPN-targeted near-infrared photoimmunotherapy (NIR-PIT) has been developed. In this therapy, toxicity to tumors is induced by an antibody-conjugated photoabsorber (IR700) after exposure to NIR light [180]. NIR-PIT selectively eliminates cancer cells, resulting in local immune reactions to cancer antigens released by destroyed cancer cells. These are characterized by the rapid maturation of dendritic cells and the stimulation of cytotoxic T cells, which attack tumor cells that have evaded the initial effects of NIR-PIT [181]. An anti-human PDPN mAb NZ-1-R700 conjugate exerts an antitumor effect in vitro and in vivo in the human MPM model [73].

In a mouse xenograft and intracranial tumor model, recombinant anti-PDPN immunotoxin (NZ-1-(scdsFv)-PE38) was evaluated for treating malignant brain tumors. NZ-1(scdsFv)-PE38 consists of the single-chain antibody variable region fragment (scFv) of NZ-1 and Pseudomonas exotoxin A (PE38). In a mouse xenograft model, NZ-1-(scdsFv)PE38 exhibited high cytotoxicity to GBM and medulloblastoma cells and demonstrated a delay in tumor growth. Crucially, in the medulloblastoma intracranial tumor model, NZ-1-(scdsFv)-PE38 caused a significant increase in survival [70].

These findings reveal that anti-PDPN mAb-drug/immunotoxin conjugates exhibited significant potential as a targeting agent for PDPN-expressing tumors.

\subsection{Radioimmunotherapy (RIT)}

RIT is an internal radiation tumor therapy that transports radionuclides using highaffinity antibodies against tumor antigens [182]. In the clinic, anti-CD20 antibodies conjugated with $\beta$-emitters, Yttrium-90 $\left({ }^{90} \mathrm{Y}\right)$ and Iodide-131 $\left({ }^{131} \mathrm{I}\right)$, have been used in hematologic malignancies, such as non-Hodgkin's lymphoma. The overall response rates are high, reaching $60-80 \%$, with a complete remission rate of $15-40 \%$ [182,183]. However, the clinical efficacy of RIT for solid tumors is still low, probably due to the low radiosensitivity of solid tumors. Anti-PDPN mAb NZ-1 conjugated with ${ }^{131} \mathrm{I}$ was first evaluated to be internalized into glioma cells and delivered to malignant glioma-bearing mice [67]. The ${ }^{131}$ I-labeled NZ-1 was efficiently internalized into LN319 GBM cells and accumulated in D2159MG GBM xenograft-bearing mice. These results showed the potential utility of NZ-1 in antibody-based therapy against GBM.

Next, the ${ }^{90}$ Y-labeled anti-PDPN antibody NZ-12 was reported to inhibit tumor growth in mesothelioma NCI-H226 xenograft-bearing mice. However, there was no complete remission [184]. Therefore, overcoming radioresistance is also essential for enhancing the clinical efficacy of RIT against solid tumors. Another anti-PDPN antibody, NZ-16 conjugated with Actinium-225 ( $\left.{ }^{225} \mathrm{Ac}\right)$, has been developed to improve the therapeutic effect of RIT using an anti-PDPN antibody. ${ }^{225} \mathrm{Ac}$ is an $\alpha$-emitter that generates four $\alpha$ particles in the decay chain [185] and has a greater linear energy transfer compared with $\beta$-emitters, resulting in more potent DNA damage to cells [186]. The antitumor effects of ${ }^{225}$ Ac-labeled NZ-16 were compared with those of ${ }^{90}$ Y-labeled NZ-16 in NCI-H226 xenograft-bearing mice. RIT with ${ }^{225} \mathrm{Ac}$ - and ${ }^{90}$ Y-labeled NZ-16 had a significantly higher antitumor effect than RIT with ${ }^{90}$ Y-labeled NZ-12. ${ }^{225} \mathrm{Ac}$-labeled NZ-16 induced larger areas of necrotic cell death, showed reduced tumor volumes, and prolonged survival, compared with ${ }^{90} \mathrm{Y}$-labeled NZ-16, without any adverse effects. These results strongly indicate that ${ }^{225}$ Ac-mediated RIT with NZ-16 is an effective and promising therapeutic option for MPM [187].

\subsection{Cancer-Specific Anti-PDPN mAbs}

A vital consideration in all tumor-targeted antibody drugs is the distribution of the target protein in normal tissues, which has significant implications for off-target effects [145]. We recently developed a cancer-specific monoclonal antibody (CasMab) method that uses flow cytometry and immunohistochemistry to select mAbs reacting with cancer cells but 
not with normal cells [188]. Using the CasMab method, we established anti-PDPN mAbs (LpMab-2 (mouse IgG I $_{\text {) L LMab-23 (mouse IgG }}$ ), and PMab-117 (rat IgM) [188,189] as well as an anti-podocalyxin mAb (PcMab-60; mouse IgM) [190]. LpMab-2 recognizes a glycopeptide of PDPN (Thr55-Leu64), which includes O-glycosylated Thr55 and/or Oglycosylated Ser56 [188] (Figure 1). LpMab-23 recognizes a naked peptide of human PDPN (Gly54-Leu64), especially Gly54, Thr55, Ser56, Glu57, Asp58, Arg59, Tyr60, and Leu64 of PDPN, and is a critical epitope of LpMab-23 [191]. PMab-117 recognizes the glycopeptide of PDPN (Ile78-Thr85), which includes O-glycosylated Thr85 (unpublished). A mouse-human chimeric mAb (chLpMab-2 [192] and chLpMab-23 [191]; human IgG $)$ exhibited high ADCC activity against PDPN-expressing cells and abolished tumor growth in xenograft models. chLpMab-23 and a mouse-human chimeric mAb of PMab-117 (chPMab-117; human IgG I $_{1}$ were also evaluated for toxicity using cynomolgus monkeys in a safety pharmacology test, and they revealed less toxicity (unpublished).

Another approach for cancer-specific anti-PDPN mAbs has been developed. The high-affinity $237 \mathrm{mAb}$ is specific for Ag104A fibrosarcoma, spontaneously developed in an aging mice [193]. The $237 \mathrm{mAb}$ did not react with other spontaneous tumors and cell lines [193,194]. The 237mAb was revealed to detect a glycopeptide of the PDPN extracellular domain that was produced as a result of a tumor-specific mutation in the Cosmc gene that abolished the enzyme core $1 \beta 1,3$-galactosyltransferase. This disrupts O-glycan core 1 synthesis, resulting in a tumor-specific glycopeptide antigen with a single Thr O-linked GalNAc (Tn antigen) [194]. In contrast to glycopeptide-specific antibodies in complex with simple peptides, $237 \mathrm{mAb}$ does not recognize a conformational epitope induced in the peptide via sugar substitution. X-ray crystallography revealed that $237 \mathrm{mAb}$ completely covers the carbohydrate moiety when interacting with the peptide in a shallow groove. Thus, $237 \mathrm{mAb}$ exhibits remarkable tumor specificity, with no physiological crossreactivity to the unglycosylated peptide or the free glycan, making it an attractive target for immunotherapy [195].

\subsection{Chimeric Antigen Receptor (CAR)-T}

Currently, several cancer immunotherapies have been developed. Among them, T-cell-mediated immunotherapy is one of the most promising strategies [196]. Overall, $\mathrm{T}$ cell receptors (TCRs) or CARs confer the antigen specificity of $\mathrm{T}$ cells. CARs have the potential to treat a broad range of cancer patients compared with TCRs. Although several CAR molecules have been developed for hematopoietic malignancy, clinical applications for solid tumors are limited, probably due to their adverse effects. The most notable form of CAR T cell toxicity is "on-target off-tumor," resulting from a direct attack against normal tissues that have shared expression of the targeted antigen. Therefore, it is critical to target specific antigens exclusively expressed on tumor cells [197].

GBM is the most prevalent and lethal primary malignant brain tumor in adults, with a 5 -year overall survival rate of less than 10\%. PDPN is overexpressed in mesenchymal GBM, which has the worst prognosis among GBM subtypes [89]. Furthermore, its therapeutic options are limited. After maximal surgical resection, the current standard care is only radiotherapy and the alkylating chemotherapeutic agent temozolomide. CAR T cells can recognize predefined tumor surface antigens independently of MHC restriction, which are often downregulated in gliomas. There is a lentiviral vector expressing a third-generation CAR, comprising an NZ-1-based scFv with CD28, 4-1BB, and CD3乙 intracellular domains. CAR-transduced peripheral blood monocytes have also been observed. The CAR T cells were found to be specific and effective against PDPN-positive GBM cells in vitro. Systemic injection of the CAR T cells into immunodeficient mice inhibited the growth of intracranial glioma xenografts in vivo. CAR T cell therapy that targets PDPN would be a promising immunotherapy for the treatment of GBM [198]. Furthermore, the use of PDPN-targeted CARs derived from a CasMab could be a promising strategy for clinical applications.

237mAb-based CAR T therapy has been developed. Unlike 237mAb, 237CAR T cells did not have exclusive specificity for cells expressing Tn-PDPN. 237CAR T cells did recog- 
nize both COSMC-mutant human and murine tumors but did not require murine PDPN expression. Recognition by 237CAR T cells was more permissive to amino acid substitutions and truncations of the Tn-glycopeptide epitope than those by 237Ab. 237CAR T cells can recognize not only Tn-PDPN, but also different Tn-glycopeptide antigens, such as Tn-TFRC, Tn-MUC1, and Tn-ZIP6 [199]. These results indicate the variations of glycopeptide recognition by full antibodies and $\mathrm{scFv}$ used in CAR. To overcome the above problem, a yeast display system of 237-scFv-CDR libraries was screened and isolated an affinity-matured variant with 30 -fold higher affinity. The affinity-matured 237 CAR appears to have lost some activity against Tn-MUC1 however, CARs showed only modestly higher levels of activity against mouse Ag104A cells, compared with wild-type 237CARs. These results suggest that an increase in affinity does not translate to an increase in potency. Using the same libraries, 237-scFv specificity variants that reacted with both Tn-PDPN and Tn-MUC1 were isolated. The specificity variants exhibited dramatically higher activity against the human tumor lines tested [200]. Thus, structure-guided engineering and selection of the single 237-scFv scaffold allowed broader cross-reactivity to human antigens carrying aberrant Tn-glycans and mediated more efficient recognition of these cancer-associated antigens.

\section{Concluding Remarks and Future Perspectives}

In this review, we have focused on the functions of PDPN in relation to the malignant progression of tumors and the strategies of PDPN-targeting tumor therapy. First, PDPN promotes cell invasion through various cellular morphologies, including EMT-like, collective, and ameboid patterns. The mechanisms of the diversity of invasion have been identified in recent years. However, there is limited information on additional physiological partners or ligands to help understand the diverse functions of PDPN. Future research will investigate the relationship between the diversity of invasion and PDPN binding proteins. Furthermore, the mechanism of stemness acquisition and/or maintenance by PDPN should be elucidated.

Second, an increasing body of evidence suggests that PDPN-positive CAFs are also involved in tumor malignancy through TME modification. The association between PDPNpositive CAFs and a TGF- $\beta$-mediated immunosuppressive TME is regarded to be significant. However, the exact molecular mechanism remains to be determined. The persistent TGF- $\beta$ signaling in the TME causes chronic immune imbalance, which could be selectively inhibited. Furthermore, PDPN functions as a co-inhibitory receptor, expressed on T cells. The elucidation of this mechanism sheds light on the molecular basis of immunosuppression by PDPN and provides a clue for cancer immunotherapy.

Third, the use of cancer-specific mAbs is a rational therapeutic strategy for minimizing adverse effects. The $237 \mathrm{mAb}$ specifically targets Tn-PDPN, but not other Tn antigens. It will be interesting to see whether this technique applies to human antigens (PDPN and others). In these cases, the selection of patients is also thought to be essential. We have established cancer-specific mAbs using the CasMab method. This technique is based on flow-cytometrymediated CasMab selection. Therefore, detailed investigations to reveal their specificity are necessary for each CasMab. Furthermore, the application of cancer-specific mAbs to CAR T cells is an attractive strategy. Careful consideration and construction of CARs are required in order to maintain tumor specificity.

Author Contributions: Writing, H.S., M.K.K. and Y.K. funding acquisition, Y.K. All authors have read and agreed to the published version of the manuscript.

Funding: This research was supported in part by Japan Agency for Medical Research and Development (AMED) under grant numbers JP21bm1004001 (Y.K.), JP21am0401013 (to Y.K.), and JP21am0101078 (to Y.K.).

Acknowledgments: We thank Nohara Goto (University of Tsukuba) for critical reading of the manuscript and preparation of figures. We appreciate current and former laboratory members for contributing research and discussion.

Conflicts of Interest: The authors declare no conflict of interest. 


\section{References}

1. Krishnan, H.; Rayes, J.; Miyashita, T.; Ishii, G.; Retzbach, E.P.; Sheehan, S.A.; Takemoto, A.; Chang, Y.W.; Yoneda, K.; Asai, J.; et al. Podoplanin: An emerging cancer biomarker and therapeutic target. Cancer Sci. 2018, 109, 1292-1299. [CrossRef]

2. Quintanilla, M.; Montero-Montero, L.; Renart, J.; Martín-Villar, E. Podoplanin in Inflammation and Cancer. Int. J. Mol. Sci. 2019, 20, 707. [CrossRef]

3. Kato, Y.; Fujita, N.; Kunita, A.; Sato, S.; Kaneko, M.; Osawa, M.; Tsuruo, T. Molecular identification of Aggrus/T1alpha as a platelet aggregation-inducing factor expressed in colorectal tumors. J. Biol. Chem. 2003, 278, 51599-51605. [CrossRef]

4. Takei, J.; Itai, S.; Harada, H.; Furusawa, Y.; Miwa, T.; Fukui, M.; Nakamura, T.; Sano, M.; Sayama, Y.; Yanaka, M.; et al. Characterization of Anti-Goat Podoplanin Monoclonal Antibody PMab-235 Using Immunohistochemistry Against Goat Tissues. Monoclon. Antib. Immunodiagn. Immunother. 2019, 38, 213-219. [CrossRef]

5. Kato, Y.; Takei, J.; Furusawa, Y.; Sayama, Y.; Sano, M.; Konnai, S.; Kobayashi, A.; Harada, H.; Takahashi, M.; Suzuki, H.; et al. Epitope Mapping of Anti-Bear Podoplanin Monoclonal Antibody PMab-247. Monoclon. Antib. Immunodiagn. Immunother. 2019, 38, $230-233$. [CrossRef]

6. Sayama, Y.; Sano, M.; Furusawa, Y.; Kaneko, M.K.; Kato, Y. Epitope Mapping of PMab-225 an Anti-Alpaca Podoplanin Monoclonal Antibody Using Flow Cytometry. Monoclon. Antib. Immunodiagn. Immunother. 2019, 38, 255-260. [CrossRef]

7. Sano, M.; Kaneko, M.K.; Kato, Y. Epitope Mapping of Monoclonal Antibody PMab-233 Against Tasmanian Devil Podoplanin. Monoclon. Antib. Immunodiagn. Immunother. 2019, 38, 261-265. [CrossRef]

8. Kato, Y.; Sayama, Y.; Sano, M.; Kaneko, M.K. Epitope Analysis of an Antihorse Podoplanin Monoclonal Antibody PMab-219. Monoclon. Antib. Immunodiagn. Immunother. 2019, 38, 266-270. [CrossRef]

9. Sayama, Y.; Sano, M.; Kaneko, M.K.; Kato, Y. Epitope Analysis of an Anti-Whale Podoplanin Monoclonal Antibody, PMab-237, Using Flow Cytometry. Monoclon. Antib. Immunodiagn. Immunother. 2020, 39, 17-22. [CrossRef]

10. Sayama, Y.; Sano, M.; Asano, T.; Furusawa, Y.; Takei, J.; Nakamura, T.; Yanaka, M.; Okamoto, S.; Handa, S.; Komatsu, Y.; et al Epitope Mapping of PMab-241, a Lymphatic Endothelial Cell-Specific Anti-Bear Podoplanin Monoclonal Antibody. Monoclon. Antib. Immunodiagn. Immunother. 2020, 39, 77-81. [CrossRef]

11. Kato, Y.; Sano, M.; Asano, T.; Sayama, Y.; Kaneko, M.K. Thr80 of Sheep Podoplanin Is a Critical Epitope of the Antisheep Podoplanin Monoclonal Antibody: PMab-256. Monoclon. Antib. Immunodiagn. Immunother. 2020, 39, 95-100. [CrossRef]

12. Sekiguchi, T.; Takemoto, A.; Takagi, S.; Takatori, K.; Sato, S.; Takami, M.; Fujita, N. Targeting a novel domain in podoplanin for inhibiting platelet-mediated tumor metastasis. Oncotarget 2016, 7, 3934-3946. [CrossRef]

13. Kaneko, M.; Kato, Y.; Kunita, A.; Fujita, N.; Tsuruo, T.; Osawa, M. Functional sialylated O-glycan to platelet aggregation on Aggrus (T1alpha/Podoplanin) molecules expressed in Chinese hamster ovary cells. J. Biol. Chem. 2004, 279, 38838-38843. [CrossRef]

14. Kaneko, M.K.; Kato, Y.; Kameyama, A.; Ito, H.; Kuno, A.; Hirabayashi, J.; Kubota, T.; Amano, K.; Chiba, Y.; Hasegawa, Y.; et al. Functional glycosylation of human podoplanin: Glycan structure of platelet aggregation-inducing factor. FEBS Lett. 2007, 581, 331-336. [CrossRef]

15. Suzuki-Inoue, K.; Kato, Y.; Inoue, O.; Kaneko, M.K.; Mishima, K.; Yatomi, Y.; Yamazaki, Y.; Narimatsu, H.; Ozaki, Y. Involvement of the snake toxin receptor CLEC-2, in podoplanin-mediated platelet activation, by cancer cells. J. Biol. Chem. 2007, 282, 25993-26001. [CrossRef]

16. Kato, Y.; Kaneko, M.K.; Kunita, A.; Ito, H.; Kameyama, A.; Ogasawara, S.; Matsuura, N.; Hasegawa, Y.; Suzuki-Inoue, K.; Inoue, O.; et al. Molecular analysis of the pathophysiological binding of the platelet aggregation-inducing factor podoplanin to the C-type lectin-like receptor CLEC-2. Cancer Sci. 2008, 99, 54-61. [CrossRef]

17. Meng, D.; Luo, M.; Liu, B. The Role of CLEC-2 and Its Ligands in Thromboinflammation. Front. Immunol. 2021, 12, 688643. [CrossRef]

18. Suzuki-Inoue, K.; Fuller, G.L.; García, A.; Eble, J.A.; Pöhlmann, S.; Inoue, O.; Gartner, T.K.; Hughan, S.C.; Pearce, A.C.; Laing, G.D.; et al. A novel Syk-dependent mechanism of platelet activation by the C-type lectin receptor CLEC-2. Blood 2006, 107, 542-549. [CrossRef]

19. Watson, A.A.; Brown, J.; Harlos, K.; Eble, J.A.; Walter, T.S.; O'Callaghan, C.A. The crystal structure and mutational binding analysis of the extracellular domain of the platelet-activating receptor CLEC-2. J. Biol. Chem. 2007, 282, 3165-3172. [CrossRef]

20. Watson, A.A.; O'Callaghan, C.A. Crystallization and X-ray diffraction analysis of human CLEC-2. Acta Cryst. Sect. F Struct. Biol. Cryst. Commun. 2005, 61, 1094-1096. [CrossRef]

21. Fuller, G.L.; Williams, J.A.; Tomlinson, M.G.; Eble, J.A.; Hanna, S.L.; Pöhlmann, S.; Suzuki-Inoue, K.; Ozaki, Y.; Watson, S.P.; Pearce, A.C. The C-type lectin receptors CLEC-2 and Dectin-1, but not DC-SIGN, signal via a novel YXXL-dependent signaling cascade. J. Biol. Chem. 2007, 282, 12397-12409. [CrossRef] [PubMed]

22. Hughes, C.E.; Auger, J.M.; McGlade, J.; Eble, J.A.; Pearce, A.C.; Watson, S.P. Differential roles for the adapters Gads and LAT in platelet activation by GPVI and CLEC-2. J. Thromb. Haemost. 2008, 6, 2152-2159. [CrossRef]

23. Ozaki, Y.; Suzuki-Inoue, K.; Inoue, O. Novel interactions in platelet biology: CLEC-2/podoplanin and laminin/GPVI. J. Thromb. Haemost. 2009, 7 (Suppl 1), 191-194. [CrossRef]

24. Kaneko, M.K.; Kato, Y.; Kitano, T.; Osawa, M. Conservation of a platelet activating domain of Aggrus/podoplanin as a platelet aggregation-inducing factor. Gene 2006, 378, 52-57. [CrossRef] 
25. Nagae, M.; Morita-Matsumoto, K.; Kato, M.; Kaneko, M.K.; Kato, Y.; Yamaguchi, Y. A platform of C-type lectin-like receptor CLEC-2 for binding O-glycosylated podoplanin and nonglycosylated rhodocytin. Structure 2014, 22, 1711-1721. [CrossRef] [PubMed]

26. Scholl, F.G.; Gamallo, C.; Vilaró, S.; Quintanilla, M. Identification of PA2.26 antigen as a novel cell-surface mucin-type glycoprotein that induces plasma membrane extensions and increased motility in keratinocytes. J. Cell Sci. 1999, 112, 4601-4613. [CrossRef]

27. Martín-Villar, E.; Megías, D.; Castel, S.; Yurrita, M.M.; Vilaró, S.; Quintanilla, M. Podoplanin binds ERM proteins to activate RhoA and promote epithelial-mesenchymal transition. J. Cell Sci. 2006, 119, 4541-4553. [CrossRef]

28. Pecora, A.; Laprise, J.; Dahmene, M.; Laurin, M. Skin Cancers and the Contribution of Rho GTPase Signaling Networks to Their Progression. Cancers 2021, 13, 4362. [CrossRef]

29. Zhang, Z.; Liu, M.; Zheng, Y. Role of Rho GTPases in stem cell regulation. Biochem. Soc. Trans. 2021, 49, 2941-2955. [CrossRef]

30. Astarita, J.L.; Acton, S.E.; Turley, S.J. Podoplanin: Emerging functions in development, the immune system, and cancer. Front. Immunol. 2012, 3, 283. [CrossRef]

31. Krishnan, H.; Retzbach, E.P.; Ramirez, M.I.; Liu, T.; Li, H.; Miller, W.T.; Goldberg, G.S. PKA and CDK5 can phosphorylate specific serines on the intracellular domain of podoplanin (PDPN) to inhibit cell motility. Exp. Cell Res. 2015, 335, 115-122. [CrossRef]

32. Rishi, A.K.; Joyce-Brady, M.; Fisher, J.; Dobbs, L.G.; Floros, J.; VanderSpek, J.; Brody, J.S.; Williams, M.C. Cloning, characterization, and development expression of a rat lung alveolar type I cell gene in embryonic endodermal and neural derivatives. Dev. Biol. 1995, 167, 294-306. [CrossRef] [PubMed]

33. Dobbs, L.G.; Williams, M.C.; Gonzalez, R. Monoclonal antibodies specific to apical surfaces of rat alveolar type I cells bind to surfaces of cultured, but not freshly isolated, type II cells. Biochim. Biophys. Acta 1988, 970, 146-156. [CrossRef]

34. Williams, M.C.; Cao, Y.; Hinds, A.; Rishi, A.K.; Wetterwald, A. T1 alpha protein is developmentally regulated and expressed by alveolar type I cells, choroid plexus, and ciliary epithelia of adult rats. Am. J. Respir. Cell Mol. Biol. 1996, 14, 577-585. [CrossRef] [PubMed]

35. Schacht, V.; Ramirez, M.I.; Hong, Y.K.; Hirakawa, S.; Feng, D.; Harvey, N.; Williams, M.; Dvorak, A.M.; Dvorak, H.F.; Oliver, G.; et al. T1alpha/podoplanin deficiency disrupts normal lymphatic vasculature formation and causes lymphedema. Embo J. 2003, 22, 3546-3556. [CrossRef] [PubMed]

36. Ramirez, M.I.; Millien, G.; Hinds, A.; Cao, Y.; Seldin, D.C.; Williams, M.C. T1alpha, a lung type I cell differentiation gene, is required for normal lung cell proliferation and alveolus formation at birth. Dev. Biol. 2003, 256, 61-72. [CrossRef]

37. Wetterwald, A.; Hoffstetter, W.; Cecchini, M.G.; Lanske, B.; Wagner, C.; Fleisch, H.; Atkinson, M. Characterization and cloning of the E11 antigen, a marker expressed by rat osteoblasts and osteocytes. Bone 1996, 18, 125-132. [CrossRef]

38. Hirakawa, S.; Hong, Y.K.; Harvey, N.; Schacht, V.; Matsuda, K.; Libermann, T.; Detmar, M. Identification of vascular lineagespecific genes by transcriptional profiling of isolated blood vascular and lymphatic endothelial cells. Am. J. Pathol. 2003, 162, 575-586. [CrossRef]

39. Petrova, T.V.; Mäkinen, T.; Mäkelä, T.P.; Saarela, J.; Virtanen, I.; Ferrell, R.E.; Finegold, D.N.; Kerjaschki, D.; Ylä-Herttuala, S.; Alitalo, K. Lymphatic endothelial reprogramming of vascular endothelial cells by the Prox-1 homeobox transcription factor. Embo J. 2002, 21, 4593-4599. [CrossRef]

40. Adams, R.H.; Alitalo, K. Molecular regulation of angiogenesis and lymphangiogenesis. Nat. Rev. Mol. Cell Biol. 2007, 8, 464-478. [CrossRef]

41. Alitalo, K.; Carmeliet, P. Molecular mechanisms of lymphangiogenesis in health and disease. Cancer Cell 2002, 1, 219-227. [CrossRef]

42. Uhrin, P.; Zaujec, J.; Breuss, J.M.; Olcaydu, D.; Chrenek, P.; Stockinger, H.; Fuertbauer, E.; Moser, M.; Haiko, P.; Fässler, R.; et al Novel function for blood platelets and podoplanin in developmental separation of blood and lymphatic circulation. Blood 2010, 115, 3997-4005. [CrossRef] [PubMed]

43. Hess, P.R.; Rawnsley, D.R.; Jakus, Z.; Yang, Y.; Sweet, D.T.; Fu, J.; Herzog, B.; Lu, M.; Nieswandt, B.; Oliver, G.; et al. Platelets mediate lymphovenous hemostasis to maintain blood-lymphatic separation throughout life. J. Clin. Investig. 2014, 124, $273-284$. [CrossRef]

44. Koop, K.; Eikmans, M.; Wehland, M.; Baelde, H.; Ijpelaar, D.; Kreutz, R.; Kawachi, H.; Kerjaschki, D.; de Heer, E.; Bruijn, J.A. Selective loss of podoplanin protein expression accompanies proteinuria and precedes alterations in podocyte morphology in a spontaneous proteinuric rat model. Am. J. Pathol. 2008, 173, 315-326. [CrossRef] [PubMed]

45. Ijpelaar, D.H.; Schulz, A.; Koop, K.; Schlesener, M.; Bruijn, J.A.; Kerjaschki, D.; Kreutz, R.; de Heer, E. Glomerular hypertrophy precedes albuminuria and segmental loss of podoplanin in podocytes in Munich-Wistar-Frömter rats. Am. J. Physiol. Ren. Physiol. 2008, 294, F758-F767. [CrossRef] [PubMed]

46. Mishima, K.; Kato, Y.; Kaneko, M.K.; Nakazawa, Y.; Kunita, A.; Fujita, N.; Tsuruo, T.; Nishikawa, R.; Hirose, T.; Matsutani, M. Podoplanin expression in primary central nervous system germ cell tumors: A useful histological marker for the diagnosis of germinoma. Acta Neuropathol. 2006, 111, 563-568. [CrossRef] [PubMed]

47. Mishima, K.; Kato, Y.; Kaneko, M.K.; Nishikawa, R.; Hirose, T.; Matsutani, M. Increased expression of podoplanin in malignant astrocytic tumors as a novel molecular marker of malignant progression. Acta Neuropathol. 2006, 111, 483-488. [CrossRef]

48. Abe, S.; Morita, Y.; Kaneko, M.K.; Hanibuchi, M.; Tsujimoto, Y.; Goto, H.; Kakiuchi, S.; Aono, Y.; Huang, J.; Sato, S.; et al. A novel targeting therapy of malignant mesothelioma using anti-podoplanin antibody. J. Immunol. 2013, 190, 6239-6249. [CrossRef] 
49. Takagi, S.; Oh-hara, T.; Sato, S.; Gong, B.; Takami, M.; Fujita, N. Expression of Aggrus/podoplanin in bladder cancer and its role in pulmonary metastasis. Int. J. Cancer 2014, 134, 2605-2614. [CrossRef]

50. Ariizumi, T.; Ogose, A.; Kawashima, H.; Hotta, T.; Li, G.; Xu, Y.; Umezu, H.; Sugai, M.; Endo, N. Expression of podoplanin in human bone and bone tumors: New marker of osteogenic and chondrogenic bone tumors. Pathol. Int. 2010, 60, 193-202. [CrossRef]

51. Chang, M.C.; Vargas, S.O.; Hornick, J.L.; Hirsch, M.S.; Crum, C.P.; Nucci, M.R. Embryonic stem cell transcription factors and D2-40 (podoplanin) as diagnostic immunohistochemical markers in ovarian germ cell tumors. Int. J. Gynecol. Pathol. 2009, 28, 347-355. [CrossRef]

52. Kato, Y.; Sasagawa, I.; Kaneko, M.; Osawa, M.; Fujita, N.; Tsuruo, T. Aggrus: A diagnostic marker that distinguishes seminoma from embryonal carcinoma in testicular germ cell tumors. Oncogene 2004, 23, 8552-8556. [CrossRef] [PubMed]

53. Suzuki, H.; Onimaru, M.; Koga, T.; Takeshita, M.; Yano, T.; Maehara, Y.; Nakamura, S.; Sueishi, K. High podoplanin expression in cancer cells predicts lower incidence of nodal metastasis in patients with lung squamous cell carcinoma. Pathol. Res. Pr. 2011, 207, 111-115. [CrossRef] [PubMed]

54. Shimada, Y.; Ishii, G.; Nagai, K.; Atsumi, N.; Fujii, S.; Yamada, A.; Yamane, Y.; Hishida, T.; Nishimura, M.; Yoshida, J.; et al. Expression of podoplanin, CD44, and p63 in squamous cell carcinoma of the lung. Cancer Sci. 2009, 100, 2054-2059. [CrossRef] [PubMed]

55. Hoshino, A.; Ishii, G.; Ito, T.; Aoyagi, K.; Ohtaki, Y.; Nagai, K.; Sasaki, H.; Ochiai, A. Podoplanin-positive fibroblasts enhance lung adenocarcinoma tumor formation: Podoplanin in fibroblast functions for tumor progression. Cancer Res. 2011, 71, 4769-4779. [CrossRef]

56. Sasaki, K.; Sugai, T.; Ishida, K.; Osakabe, M.; Amano, H.; Kimura, H.; Sakuraba, M.; Kashiwa, K.; Kobayashi, S. Analysis of cancer-associated fibroblasts and the epithelial-mesenchymal transition in cutaneous basal cell carcinoma, squamous cell carcinoma, and malignant melanoma. Hum. Pathol. 2018, 79, 1-8. [CrossRef]

57. Suzuki, J.; Aokage, K.; Neri, S.; Sakai, T.; Hashimoto, H.; Su, Y.; Yamazaki, S.; Nakamura, H.; Tane, K.; Miyoshi, T.; et al Relationship between podoplanin-expressing cancer-associated fibroblasts and the immune microenvironment of early lung squamous cell carcinoma. Lung Cancer 2021, 153, 1-10. [CrossRef] [PubMed]

58. Pula, B.; Jethon, A.; Piotrowska, A.; Gomulkiewicz, A.; Owczarek, T.; Calik, J.; Wojnar, A.; Witkiewicz, W.; Rys, J.; Ugorski, M.; et al. Podoplanin expression by cancer-associated fibroblasts predicts poor outcome in invasive ductal breast carcinoma. Histopathology 2011, 59, 1249-1260. [CrossRef]

59. Shindo, K.; Aishima, S.; Ohuchida, K.; Fujiwara, K.; Fujino, M.; Mizuuchi, Y.; Hattori, M.; Mizumoto, K.; Tanaka, M.; Oda, Y. Podoplanin expression in cancer-associated fibroblasts enhances tumor progression of invasive ductal carcinoma of the pancreas. Mol. Cancer 2013, 12, 168. [CrossRef]

60. Yoshida, T.; Ishii, G.; Goto, K.; Neri, S.; Hashimoto, H.; Yoh, K.; Niho, S.; Umemura, S.; Matsumoto, S.; Ohmatsu, H.; et al Podoplanin-positive cancer-associated fibroblasts in the tumor microenvironment induce primary resistance to EGFR-TKIs in lung adenocarcinoma with EGFR mutation. Clin. Cancer Res. 2015, 21, 642-651. [CrossRef]

61. Sakai, T.; Aokage, K.; Neri, S.; Nakamura, H.; Nomura, S.; Tane, K.; Miyoshi, T.; Sugano, M.; Kojima, M.; Fujii, S.; et al Link between tumor-promoting fibrous microenvironment and an immunosuppressive microenvironment in stage I lung adenocarcinoma. Lung Cancer 2018, 126, 64-71. [CrossRef] [PubMed]

62. Kalof, A.N.; Cooper, K. D2-40 immunohistochemistry-So far! Adv. Anat. Pathol. 2009, 16, 62-64. [CrossRef] [PubMed]

63. Marks, A.; Sutherland, D.R.; Bailey, D.; Iglesias, J.; Law, J.; Lei, M.; Yeger, H.; Banerjee, D.; Baumal, R. Characterization and distribution of an oncofetal antigen (M2A antigen) expressed on testicular germ cell tumours. Br. J. Cancer 1999, 80, 569-578. [CrossRef] [PubMed]

64. Schacht, V.; Dadras, S.S.; Johnson, L.A.; Jackson, D.G.; Hong, Y.K.; Detmar, M. Up-regulation of the lymphatic marker podoplanin, a mucin-type transmembrane glycoprotein, in human squamous cell carcinomas and germ cell tumors. Am. J. Pathol. 2005, 166, 913-921. [CrossRef]

65. Ogasawara, S.; Kaneko, M.K.; Price, J.E.; Kato, Y. Characterization of anti-podoplanin monoclonal antibodies: Critical epitopes for neutralizing the interaction between podoplanin and CLEC-2. Hybridoma 2008, 27, 259-267. [CrossRef]

66. Kato, Y.; Kaneko, M.K.; Kuno, A.; Uchiyama, N.; Amano, K.; Chiba, Y.; Hasegawa, Y.; Hirabayashi, J.; Narimatsu, H.; Mishima, K.; et al. Inhibition of tumor cell-induced platelet aggregation using a novel anti-podoplanin antibody reacting with its plateletaggregation-stimulating domain. Biochem. Biophys. Res. Commun. 2006, 349, 1301-1307. [CrossRef]

67. Kato, Y.; Vaidyanathan, G.; Kaneko, M.K.; Mishima, K.; Srivastava, N.; Chandramohan, V.; Pegram, C.; Keir, S.T.; Kuan, C.T.; Bigner, D.D.; et al. Evaluation of anti-podoplanin rat monoclonal antibody NZ-1 for targeting malignant gliomas. Nucl. Med. Biol. 2010, 37, 785-794. [CrossRef] [PubMed]

68. Kaneko, M.K.; Kunita, A.; Abe, S.; Tsujimoto, Y.; Fukayama, M.; Goto, K.; Sawa, Y.; Nishioka, Y.; Kato, Y. Chimeric anti-podoplanin antibody suppresses tumor metastasis through neutralization and antibody-dependent cellular cytotoxicity. Cancer Sci. 2012, 103, 1913-1919. [CrossRef]

69. Kaji, C.; Tsujimoto, Y.; Kato Kaneko, M.; Kato, Y.; Sawa, Y. Immunohistochemical Examination of Novel Rat Monoclonal Antibodies against Mouse and Human Podoplanin. Acta Histochem. Cytochem. 2012, 45, 227-237. [CrossRef] 
70. Chandramohan, V.; Bao, X.; Kato Kaneko, M.; Kato, Y.; Keir, S.T.; Szafranski, S.E.; Kuan, C.T.; Pastan, I.H.; Bigner, D.D. Recombinant anti-podoplanin (NZ-1) immunotoxin for the treatment of malignant brain tumors. Int. J. Cancer 2013, 132, 2339-2348. [CrossRef]

71. Bieniasz-Krzywiec, P.; Martin-Perez, R.; Ehling, M.; Garcia-Caballero, M.; Pinioti, S.; Pretto, S.; Kroes, R.; Aldeni, C.; Di Matteo, M.; Prenen, H.; et al. Podoplanin-Expressing Macrophages Promote Lymphangiogenesis and Lymphoinvasion in Breast Cancer. Cell Metab. 2019, 30, 917-936. [CrossRef] [PubMed]

72. Kuwata, T.; Yoneda, K.; Mori, M.; Kanayama, M.; Kuroda, K.; Kaneko, M.K.; Kato, Y.; Tanaka, F. Detection of Circulating Tumor Cells (CTCs) in Malignant Pleural Mesothelioma (MPM) with the "Universal" CTC-Chip and An Anti-Podoplanin Antibody NZ-1.2. Cells 2020, 9, 888. [CrossRef] [PubMed]

73. Nishinaga, Y.; Sato, K.; Yasui, H.; Taki, S.; Takahashi, K.; Shimizu, M.; Endo, R.; Koike, C.; Kuramoto, N.; Nakamura, S.; et al. Targeted Phototherapy for Malignant Pleural Mesothelioma: Near-Infrared Photoimmunotherapy Targeting Podoplanin. Cells 2020, 9, 1019. [CrossRef]

74. Ando, K.; Fujino, N.; Mitani, K.; Ota, C.; Okada, Y.; Kondo, T.; Mizobuchi, T.; Kurihara, M.; Suzuki, K.; Hoshika, Y.; et al. Isolation of individual cellular components from lung tissues of patients with lymphangioleiomyomatosis. Am. J. Physiol. Lung Cell Mol. Physiol. 2016, 310, L899-L908. [CrossRef]

75. Fujii, Y.; Kaneko, M.; Neyazaki, M.; Nogi, T.; Kato, Y.; Takagi, J. PA tag: A versatile protein tagging system using a super high affinity antibody against a dodecapeptide derived from human podoplanin. Protein Expr. Purif. 2014, 95, 240-247. [CrossRef]

76. Fujii, Y.; Matsunaga, Y.; Arimori, T.; Kitago, Y.; Ogasawara, S.; Kaneko, M.K.; Kato, Y.; Takagi, J. Tailored placement of a turn-forming PA tag into the structured domain of a protein to probe its conformational state. J. Cell Sci. 2016, 129, 1512-1522. [CrossRef]

77. Tamura, R.; Oi, R.; Akashi, S.; Kaneko, M.K.; Kato, Y.; Nogi, T. Application of the NZ-1 Fab as a crystallization chaperone for PA tag-inserted target proteins. Protein Sci. 2019, 28, 823-836. [CrossRef]

78. Yoneda, K.; Kuwata, T.; Chikaishi, Y.; Mori, M.; Kanayama, M.; Takenaka, M.; Oka, S.; Hirai, A.; Imanishi, N.; Kuroda, K.; et al Detection of circulating tumor cells with a novel microfluidic system in malignant pleural mesothelioma. Cancer Sci. 2019, 110, 726-733. [CrossRef]

79. Yoneda, K.; Chikaishi, Y.; Kuwata, T.; Ohnaga, T.; Tanaka, F. Capture of mesothelioma cells with 'universal' CTC-chip. Oncol. Lett. 2018, 15, 2635-2640. [CrossRef] [PubMed]

80. Kanayama, M.; Oyama, R.; Mori, M.; Taira, A.; Shinohara, S.; Kuwata, T.; Takenaka, M.; Yoneda, K.; Kuroda, K.; Ohnaga, T.; et al. Novel circulating tumor cell-detection chip combining conventional podoplanin and EGFR antibodies for all histological malignant pleural mesothelioma. Oncol. Lett. 2021, 22, 522. [CrossRef]

81. Tanaka, M.; Kijima, H.; Shimada, H.; Makuuchi, H.; Ozawa, S.; Inokuchi, S. Expression of podoplanin and vimentin is correlated with prognosis in esophageal squamous cell carcinoma. Mol. Med. Rep. 2015, 12, 4029-4036. [CrossRef] [PubMed]

82. Rahadiani, N.; Ikeda, J.; Makino, T.; Tian, T.; Qiu, Y.; Mamat, S.; Wang, Y.; Doki, Y.; Aozasa, K.; Morii, E. Tumorigenic role of podoplanin in esophageal squamous-cell carcinoma. Ann. Surg. Oncol. 2010, 17, 1311-1323. [CrossRef]

83. Nakashima, Y.; Yoshinaga, K.; Kitao, H.; Ando, K.; Kimura, Y.; Saeki, H.; Oki, E.; Morita, M.; Kakeji, Y.; Hirahashi, M.; et al Podoplanin is expressed at the invasive front of esophageal squamous cell carcinomas and is involved in collective cell invasion. Cancer Sci. 2013, 104, 1718-1725. [CrossRef] [PubMed]

84. Kreppel, M.; Scheer, M.; Drebber, U.; Ritter, L.; Zöller, J.E. Impact of podoplanin expression in oral squamous cell carcinoma: Clinical and histopathologic correlations. Virchows Arch. 2010, 456, 473-482. [CrossRef] [PubMed]

85. Kreppel, M.; Drebber, U.; Wedemeyer, I.; Eich, H.T.; Backhaus, T.; Zöller, J.E.; Scheer, M. Podoplanin expression predicts prognosis in patients with oral squamous cell carcinoma treated with neoadjuvant radiochemotherapy. Oral Oncol. 2011, 47, 873-878. [CrossRef]

86. Vinicius de, L.V.; Scapulatempo, C.; Perpetuo, N.M.; Mohamed, F.; de Carvalho, T.S.; de Oliveira, A.T.; Segalla, J.G.; Carvalho, A.L. Prognostic and risk factors in patients with locally advanced cutaneous squamous cell carcinoma of the trunk and extremities. J. Ski. Cancer 2011, 2011, 420796. [CrossRef]

87. Kim, H.Y.; Rha, K.S.; Shim, G.A.; Kim, J.H.; Kim, J.M.; Huang, S.M.; Koo, B.S. Podoplanin is involved in the prognosis of head and neck squamous cell carcinoma through interaction with VEGF-C. Oncol. Rep. 2015, 34, 833-842. [CrossRef]

88. Xia, Y.; Liu, L.; Xiong, Y.; Bai, Q.; Wang, J.; Xi, W.; Qu, Y.; Xu, J.; Guo, J. Podoplanin associates with adverse postoperative prognosis of patients with clear cell renal cell carcinoma. Cancer Sci. 2016, 107, 1243-1249. [CrossRef]

89. Motomura, K.; Natsume, A.; Watanabe, R.; Ito, I.; Kato, Y.; Momota, H.; Nishikawa, R.; Mishima, K.; Nakasu, Y.; Abe, T.; et al. Immunohistochemical analysis-based proteomic subclassification of newly diagnosed glioblastomas. Cancer Sci. 2012, 103, 1871-1879. [CrossRef]

90. Schoppmann, S.F.; Jesch, B.; Riegler, M.F.; Maroske, F.; Schwameis, K.; Jomrich, G.; Birner, P. Podoplanin expressing cancer associated fibroblasts are associated with unfavourable prognosis in adenocarcinoma of the esophagus. Clin. Exp. Metastasis 2013, 30, 441-446. [CrossRef]

91. Obulkasim, H.; Shi, X.; Wang, J.; Li, J.; Dai, B.; Wu, P.; Wang, S.; Wang, X.; Ding, Y. Podoplanin is an important stromal prognostic marker in perihilar cholangiocarcinoma. Oncol. Lett. 2018, 15, 137-146. [CrossRef] [PubMed]

92. Hantusch, B.; Kalt, R.; Krieger, S.; Puri, C.; Kerjaschki, D. Sp1/Sp3 and DNA-methylation contribute to basal transcriptional activation of human podoplanin in MG63 versus Saos-2 osteoblastic cells. BMC Mol. Biol. 2007, 8, 20. [CrossRef] [PubMed] 
93. Durchdewald, M.; Guinea-Viniegra, J.; Haag, D.; Riehl, A.; Lichter, P.; Hahn, M.; Wagner, E.F.; Angel, P.; Hess, J. Podoplanin is a novel fos target gene in skin carcinogenesis. Cancer Res. 2008, 68, 6877-6883. [CrossRef] [PubMed]

94. Kunita, A.; Kashima, T.G.; Ohazama, A.; Grigoriadis, A.E.; Fukayama, M. Podoplanin is regulated by AP-1 and promotes platelet aggregation and cell migration in osteosarcoma. Am. J. Pathol. 2011, 179, 1041-1049. [CrossRef] [PubMed]

95. Shen, Y.; Chen, C.S.; Ichikawa, H.; Goldberg, G.S. SRC induces podoplanin expression to promote cell migration. J. Biol. Chem. 2010, 285, 9649-9656. [CrossRef]

96. Peterziel, H.; Müller, J.; Danner, A.; Barbus, S.; Liu, H.K.; Radlwimmer, B.; Pietsch, T.; Lichter, P.; Schütz, G.; Hess, J.; et al Expression of podoplanin in human astrocytic brain tumors is controlled by the PI3K-AKT-AP-1 signaling pathway and promoter methylation. Neuro. Oncol. 2012, 14, 426-439. [CrossRef] [PubMed]

97. Mei, Y.; Zhang, P.; Zuo, H.; Clark, D.; Xia, R.; Li, J.; Liu, Z.; Mao, L. Ebp1 activates podoplanin expression and contributes to oral tumorigenesis. Oncogene 2014, 33, 3839-3850. [CrossRef]

98. Kunita, A.; Baeriswyl, V.; Meda, C.; Cabuy, E.; Takeshita, K.; Giraudo, E.; Wicki, A.; Fukayama, M.; Christofori, G. Inflammatory Cytokines Induce Podoplanin Expression at the Tumor Invasive Front. Am. J. Pathol. 2018, 188, 1276-1288. [CrossRef]

99. Ohta, M.; Abe, A.; Ohno, F.; Hasegawa, Y.; Tanaka, H.; Maseki, S.; Kondo, E.; Kurita, K.; Nakanishi, H. Positive and negative regulation of podoplanin expression by TGF- $\beta$ and histone deacetylase inhibitors in oral and pharyngeal squamous cell carcinoma cell lines. Oral Oncol. 2013, 49, 20-26. [CrossRef]

100. Suzuki, H.; Kato, Y.; Kaneko, M.K.; Okita, Y.; Narimatsu, H.; Kato, M. Induction of podoplanin by transforming growth factor-beta in human fibrosarcoma. FEBS Lett. 2008, 582, 341-345. [CrossRef]

101. Hanahan, D.; Weinberg, R.A. Hallmarks of cancer: The next generation. Cell 2011, 144, 646-674. [CrossRef]

102. Lambert, A.W.; Weinberg, R.A. Linking EMT programmes to normal and neoplastic epithelial stem cells. Nat. Rev. Cancer 2021, 21, 325-338. [CrossRef] [PubMed]

103. Yang, J.; Antin, P.; Berx, G.; Blanpain, C.; Brabletz, T.; Bronner, M.; Campbell, K.; Cano, A.; Casanova, J.; Christofori, G.; et al. Guidelines and definitions for research on epithelial-mesenchymal transition. Nat. Rev. Mol. Cell Biol. 2020, 21, 341-352. [CrossRef] [PubMed]

104. Renart, J.; Carrasco-Ramírez, P.; Fernández-Muñoz, B.; Martín-Villar, E.; Montero, L.; Yurrita, M.M.; Quintanilla, M. New insights into the role of podoplanin in epithelial-mesenchymal transition. Int. Rev. Cell Mol. Biol. 2015, 317, 185-239. [CrossRef]

105. Senbanjo, L.T.; Chellaiah, M.A. CD44: A Multifunctional Cell Surface Adhesion Receptor Is a Regulator of Progression and Metastasis of Cancer Cells. Front. Cell Dev. Biol. 2017, 5, 18. [CrossRef] [PubMed]

106. Martín-Villar, E.; Fernández-Muñoz, B.; Parsons, M.; Yurrita, M.M.; Megías, D.; Pérez-Gómez, E.; Jones, G.E.; Quintanilla, M. Podoplanin associates with CD44 to promote directional cell migration. Mol. Biol. Cell 2010, 21, 4387-4399. [CrossRef]

107. Li, Y.Y.; Zhou, C.X.; Gao, Y. Podoplanin promotes the invasion of oral squamous cell carcinoma in coordination with MT1-MMP and Rho GTPases. Am. J. Cancer Res. 2015, 5, 514-529. [PubMed]

108. Asif, P.J.; Longobardi, C.; Hahne, M.; Medema, J.P. The Role of Cancer-Associated Fibroblasts in Cancer Invasion and Metastasis. Cancers 2021, 13, 4720. [CrossRef]

109. Li, Y.Y.; Zhou, C.X.; Gao, Y. Interaction between oral squamous cell carcinoma cells and fibroblasts through TGF- $\beta 1$ mediated by podoplanin. Exp. Cell Res. 2018, 369, 43-53. [CrossRef] [PubMed]

110. Masi, I.; Caprara, V.; Bagnato, A.; Rosanò, L. Tumor Cellular and Microenvironmental Cues Controlling Invadopodia Formation. Front. Cell Dev. Biol. 2020, 8, 584181. [CrossRef]

111. Aseervatham, J. Cytoskeletal Remodeling in Cancer. Biology 2020, 9, 385. [CrossRef]

112. Martín-Villar, E.; Borda-d'Agua, B.; Carrasco-Ramirez, P.; Renart, J.; Parsons, M.; Quintanilla, M.; Jones, G.E. Podoplanin mediates ECM degradation by squamous carcinoma cells through control of invadopodia stability. Oncogene 2015, 34, 4531-4544. [CrossRef] [PubMed]

113. Hwang, Y.S.; Xianglan, Z.; Park, K.K.; Chung, W.Y. Functional invadopodia formation through stabilization of the PDPN transcript by IMP-3 and cancer-stromal crosstalk for PDPN expression. Carcinogenesis 2012, 33, 2135-2146. [CrossRef] [PubMed]

114. Zhao, P.; Xu, Y.; Wei, Y.; Qiu, Q.; Chew, T.L.; Kang, Y.; Cheng, C. The CD44s splice isoform is a central mediator for invadopodia activity. J. Cell Sci. 2016, 129, 1355-1365. [CrossRef]

115. Grass, G.D.; Tolliver, L.B.; Bratoeva, M.; Toole, B.P. CD147, CD44, and the epidermal growth factor receptor (EGFR) signaling pathway cooperate to regulate breast epithelial cell invasiveness. J. Biol. Chem. 2013, 288, 26089-26104. [CrossRef]

116. Te Boekhorst, V.; Preziosi, L.; Friedl, P. Plasticity of Cell Migration In Vivo and In Silico. Annu. Rev. Cell Dev. Biol. 2016, 32, 491-526. [CrossRef] [PubMed]

117. Van Helvert, S.; Storm, C.; Friedl, P. Mechanoreciprocity in cell migration. Nat. Cell Biol. 2018, 20, 8-20. [CrossRef]

118. Stuelten, C.H.; Parent, C.A.; Montell, D.J. Cell motility in cancer invasion and metastasis: Insights from simple model organisms. Nat. Rev. Cancer 2018, 18, 296-312. [CrossRef]

119. Wicki, A.; Lehembre, F.; Wick, N.; Hantusch, B.; Kerjaschki, D.; Christofori, G. Tumor invasion in the absence of epithelialmesenchymal transition: Podoplanin-mediated remodeling of the actin cytoskeleton. Cancer Cell 2006, 9, 261-272. [CrossRef]

120. Tozluoğlu, M.; Tournier, A.L.; Jenkins, R.P.; Hooper, S.; Bates, P.A.; Sahai, E. Matrix geometry determines optimal cancer cell migration strategy and modulates response to interventions. Nat. Cell Biol. 2013, 15, 751-762. [CrossRef]

121. Pandya, P.; Orgaz, J.L.; Sanz-Moreno, V. Modes of invasion during tumour dissemination. Mol. Oncol. 2017, 11, 5-27. [CrossRef] 
122. Wyckoff, J.B.; Pinner, S.E.; Gschmeissner, S.; Condeelis, J.S.; Sahai, E. ROCK- and myosin-dependent matrix deformation enables protease-independent tumor-cell invasion in vivo. Curr. Biol. 2006, 16, 1515-1523. [CrossRef] [PubMed]

123. De Winde, C.M.; George, S.L.; Crosas-Molist, E.; Hari-Gupta, Y.; Arp, A.B.; Benjamin, A.C.; Millward, L.J.; Makris, S.; Carver, A.; Imperatore, V.; et al. Podoplanin drives dedifferentiation and amoeboid invasion of melanoma. iScience 2021, $24,102976$. [CrossRef] [PubMed]

124. Braun, A.; Anders, H.J.; Gudermann, T.; Mammadova-Bach, E. Platelet-Cancer Interplay: Molecular Mechanisms and New Therapeutic Avenues. Front. Oncol. 2021, 11, 665534. [CrossRef] [PubMed]

125. Takemoto, A.; Miyata, K.; Fujita, N. Platelet-activating factor podoplanin: From discovery to drug development. Cancer Metastasis Rev. 2017, 36, 225-234. [CrossRef] [PubMed]

126. Fujita, N.; Takagi, S. The impact of Aggrus/podoplanin on platelet aggregation and tumour metastasis. J. Biochem. 2012, 152, 407-413. [CrossRef] [PubMed]

127. David, C.J.; Massagué, J. Contextual determinants of TGF $\beta$ action in development, immunity and cancer. Nat. Rev. Mol. Cell Biol. 2018, 19, 419-435. [CrossRef]

128. Wilson, M.M.; Weinberg, R.A.; Lees, J.A.; Guen, V.J. Emerging Mechanisms by which EMT Programs Control Stemness. Trends Cancer 2020, 6, 775-780. [CrossRef]

129. Atsumi, N.; Ishii, G.; Kojima, M.; Sanada, M.; Fujii, S.; Ochiai, A. Podoplanin, a novel marker of tumor-initiating cells in human squamous cell carcinoma A431. Biochem. Biophys. Res. Commun. 2008, 373, 36-41. [CrossRef]

130. Miyashita, T.; Higuchi, Y.; Kojima, M.; Ochiai, A.; Ishii, G. Single cell time-lapse analysis reveals that podoplanin enhances cell survival and colony formation capacity of squamous cell carcinoma cells. Sci. Rep. 2017, 7, 39971. [CrossRef]

131. Miyashita, T.; Neri, S.; Hashimoto, H.; Akutsu, A.; Sugano, M.; Fujii, S.; Ochiai, A.; Ishii, G. Fibroblasts-dependent invasion of podoplanin-positive cancer stem cells in squamous cell carcinoma. J. Cell Physiol. 2020, 235, 7251-7260. [CrossRef] [PubMed]

132. Ito, M.; Ishii, G.; Nagai, K.; Maeda, R.; Nakano, Y.; Ochiai, A. Prognostic impact of cancer-associated stromal cells in patients with stage I lung adenocarcinoma. Chest 2012, 142, 151-158. [CrossRef] [PubMed]

133. Ito, S.; Ishii, G.; Hoshino, A.; Hashimoto, H.; Neri, S.; Kuwata, T.; Higashi, M.; Nagai, K.; Ochiai, A. Tumor promoting effect of podoplanin-positive fibroblasts is mediated by enhanced RhoA activity. Biochem. Biophys. Res. Commun. 2012, 422, 194-199. [CrossRef] [PubMed]

134. Neri, S.; Ishii, G.; Taira, T.; Hishida, T.; Yoshida, J.; Nishimura, M.; Nagai, K.; Ochiai, A. Recruitment of podoplanin positive cancer-associated fibroblasts in metastatic lymph nodes predicts poor prognosis in pathological N2 stage III lung adenocarcinoma. Ann. Surg. Oncol. 2012, 19, 3953-3962. [CrossRef]

135. Nakamura, H.; Ichikawa, T.; Nakasone, S.; Miyoshi, T.; Sugano, M.; Kojima, M.; Fujii, S.; Ochiai, A.; Kuwata, T.; Aokage, K.; et al. Abundant tumor promoting stromal cells in lung adenocarcinoma with hypoxic regions. Lung Cancer 2018, 115, 56-63. [CrossRef]

136. Komohara, Y.; Jinushi, M.; Takeya, M. Clinical significance of macrophage heterogeneity in human malignant tumors. Cancer Sci. 2014, 105, 1-8. [CrossRef]

137. Fridman, W.H.; Pagès, F.; Sautès-Fridman, C.; Galon, J. The immune contexture in human tumours: Impact on clinical outcome. Nat. Rev. Cancer 2012, 12, 298-306. [CrossRef]

138. Chen, W.; Ten Dijke, P. Immunoregulation by members of the TGF $\beta$ superfamily. Nat. Rev. Immunol. 2016, 16, 723-740. [CrossRef]

139. Liu, S.; Ren, J.; Ten Dijke, P. Targeting TGF $\beta$ signal transduction for cancer therapy. Signal. Transduct. Target 2021, 6, 8. [CrossRef]

140. Chihara, N.; Madi, A.; Kondo, T.; Zhang, H.; Acharya, N.; Singer, M.; Nyman, J.; Marjanovic, N.D.; Kowalczyk, M.S.; Wang, C.; et al. Induction and transcriptional regulation of the co-inhibitory gene module in T cells. Nature 2018, 558, 454-459. [CrossRef]

141. Peters, A.; Burkett, P.R.; Sobel, R.A.; Buckley, C.D.; Watson, S.P.; Bettelli, E.; Kuchroo, V.K. Podoplanin negatively regulates CD4+ effector T cell responses. J. Clin. Investig. 2015, 125, 129-140. [CrossRef]

142. Li, F.; Chen, Y.; Pang, M.; Yang, P.; Jing, H. Immune checkpoint inhibitors and cellular treatment for lymphoma immunotherapy. Clin. Exp. Immunol. 2021, 205, 1-11. [CrossRef]

143. Qin, S.; Xu, L.; Yi, M.; Yu, S.; Wu, K.; Luo, S. Novel immune checkpoint targets: Moving beyond PD-1 and CTLA-4. Mol. Cancer 2019, 18, 155. [CrossRef] [PubMed]

144. Astarita, J.L.; Keerthivasan, S.; Husain, B.; Şenbabaoğlu, Y.; Verschueren, E.; Gierke, S.; Pham, V.C.; Peterson, S.M.; Chalouni, C.; Pierce, A.A.; et al. The neutrophil protein CD177 is a novel PDPN receptor that regulates human cancer-associated fibroblast physiology. PLoS ONE 2021, 16, e0260800. [CrossRef]

145. Tsao, L.C.; Force, J.; Hartman, Z.C. Mechanisms of Therapeutic Antitumor Monoclonal Antibodies. Cancer Res. 2021, 81, 4641-4651. [CrossRef] [PubMed]

146. Li, B.T.; Smit, E.F.; Goto, Y.; Nakagawa, K.; Udagawa, H.; Mazières, J.; Nagasaka, M.; Bazhenova, L.; Saltos, A.N.; Felip, E.; et al. Trastuzumab Deruxtecan in HER2-Mutant Non-Small-Cell Lung Cancer. N. Engl. J. Med. 2021, 386, 241-251. [CrossRef] [PubMed]

147. Modi, S.; Saura, C.; Yamashita, T.; Park, Y.H.; Kim, S.B.; Tamura, K.; Andre, F.; Iwata, H.; Ito, Y.; Tsurutani, J.; et al. Trastuzumab Deruxtecan in Previously Treated HER2-Positive Breast Cancer. N. Engl. J. Med. 2020, 382, 610-621. [CrossRef] [PubMed]

148. Shitara, K.; Bang, Y.J.; Iwasa, S.; Sugimoto, N.; Ryu, M.H.; Sakai, D.; Chung, H.C.; Kawakami, H.; Yabusaki, H.; Lee, J.; et al Trastuzumab Deruxtecan in Previously Treated HER2-Positive Gastric Cancer. N. Engl. J. Med. 2020, 382, 2419-2430. [CrossRef]

149. Heath, E.I.; Rosenberg, J.E. The biology and rationale of targeting nectin-4 in urothelial carcinoma. Nat. Rev. Urol. 2021, 18, 93-103. [CrossRef] 
150. Bardia, A.; Hurvitz, S.A.; Tolaney, S.M.; Loirat, D.; Punie, K.; Oliveira, M.; Brufsky, A.; Sardesai, S.D.; Kalinsky, K.; Zelnak, A.B.; et al. Sacituzumab Govitecan in Metastatic Triple-Negative Breast Cancer. N. Engl. J. Med. 2021, 384, 1529-1541. [CrossRef]

151. Goldenberg, D.M.; Stein, R.; Sharkey, R.M. The emergence of trophoblast cell-surface antigen 2 (TROP-2) as a novel cancer target. Oncotarget 2018, 9, 28989-29006. [CrossRef] [PubMed]

152. Nakazawa, Y.; Takagi, S.; Sato, S.; Oh-hara, T.; Koike, S.; Takami, M.; Arai, H.; Fujita, N. Prevention of hematogenous metastasis by neutralizing mice and its chimeric anti-Aggrus/podoplanin antibodies. Cancer Sci. 2011, 102, 2051-2057. [CrossRef] [PubMed]

153. Takagi, S.; Sato, S.; Oh-hara, T.; Takami, M.; Koike, S.; Mishima, Y.; Hatake, K.; Fujita, N. Platelets promote tumor growth and metastasis via direct interaction between Aggrus/podoplanin and CLEC-2. PLoS ONE 2013, 8, e73609. [CrossRef] [PubMed]

154. Ukaji, T.; Takemoto, A.; Katayama, R.; Takeuchi, K.; Fujita, N. A safety study of newly generated anti-podoplanin-neutralizing antibody in cynomolgus monkey (Macaca fascicularis). Oncotarget 2018, 9, 33322-33336. [CrossRef] [PubMed]

155. Kato, Y.; Kunita, A.; Abe, S.; Ogasawara, S.; Fujii, Y.; Oki, H.; Fukayama, M.; Nishioka, Y.; Kaneko, M.K. The chimeric antibody chLpMab-7 targeting human podoplanin suppresses pulmonary metastasis via ADCC and CDC rather than via its neutralizing activity. Oncotarget 2015, 6, 36003-36018. [CrossRef]

156. Scott, A.M.; Wolchok, J.D.; Old, L.J. Antibody therapy of cancer. Nat. Rev. Cancer 2012, 12, 278-287. [CrossRef]

157. Zahavi, D.; Weiner, L. Monoclonal Antibodies in Cancer Therapy. Antibodies 2020, 9, 34. [CrossRef]

158. Kaneko, M.K.; Honma, R.; Ogasawara, S.; Fujii, Y.; Nakamura, T.; Saidoh, N.; Takagi, M.; Kagawa, Y.; Konnai, S.; Kato, Y. PMab-38 Recognizes Canine Podoplanin of Squamous Cell Carcinomas. Monoclon. Antib. Immunodiagn. Immunother. 2016, 35, $263-266$. [CrossRef]

159. Ito, A.; Ohta, M.; Kato, Y.; Inada, S.; Kato, T.; Nakata, S.; Yatabe, Y.; Goto, M.; Kaneda, N.; Kurita, K.; et al. A Real-Time Near-Infrared Fluorescence Imaging Method for the Detection of Oral Cancers in Mice Using an Indocyanine Green-Labeled Podoplanin Antibody. Technol. Cancer Res. Treat. 2018, 17, 1533033818767936. [CrossRef]

160. Kato, Y.; Ohishi, T.; Kawada, M.; Maekawa, N.; Konnai, S.; Itai, S.; Yamada, S.; Kaneko, M.K. The mouse-canine chimeric anti-dog podoplanin antibody P38B exerts antitumor activity in mouse xenograft models. Biochem. Biophys. Rep. 2019, 17, 23-26. [CrossRef]

161. Kato, Y.; Ito, Y.; Ohishi, T.; Kawada, M.; Nakamura, T.; Sayama, Y.; Sano, M.; Asano, T.; Yanaka, M.; Okamoto, S.; et al. AntibodyDrug Conjugates Using Mouse-Canine Chimeric Anti-Dog Podoplanin Antibody Exerts Antitumor Activity in a Mouse Xenograft Model. Monoclon. Antib. Immunodiagn. Immunother. 2020, 39, 37-44. [CrossRef]

162. Pantelyushin, S.; Ranninger, E.; Guerrera, D.; Hutter, G.; Maake, C.; Markkanen, E.; Bettschart-Wolfensberger, R.; Rohrer Bley, C.; Läubli, H.; Vom Berg, J. Cross-Reactivity and Functionality of Approved Human Immune Checkpoint Blockers in Dogs. Cancers 2021, 13, 785. [CrossRef]

163. Maekawa, N.; Konnai, S.; Nishimura, M.; Kagawa, Y.; Takagi, S.; Hosoya, K.; Ohta, H.; Kim, S.; Okagawa, T.; Izumi, Y.; et al. PD-L1 immunohistochemistry for canine cancers and clinical benefit of anti-PD-L1 antibody in dogs with pulmonary metastatic oral malignant melanoma. NPJ Precis. Oncol. 2021, 5, 10. [CrossRef] [PubMed]

164. Klingemann, H. Immunotherapy for Dogs: Running Behind Humans. Front. Immunol. 2018, 9, 133. [CrossRef] [PubMed]

165. Tanaka, T.; Asano, T.; Sano, M.; Takei, J.; Hosono, H.; Nanamiya, R.; Nakamura, T.; Yanaka, M.; Harada, H.; Fukui, M.; et al. Development of Monoclonal Antibody PMab-269 Against California Sea Lion Podoplanin. Monoclon. Antib. Immunodiagn. Immunother. 2021, 40, 124-133. [CrossRef] [PubMed]

166. Hosono, H.; Asano, T.; Takei, J.; Sano, M.; Tanaka, T.; Kaneko, M.K.; Kato, Y. Development of an Anti-Elephant Podoplanin Monoclonal Antibody PMab-265 for Flow Cytometry. Monoclon. Antib. Immunodiagn. Immunother. 2021, 40, 141-145. [CrossRef]

167. Kato, Y.; Furusawa, Y.; Sano, M.; Takei, J.; Nakamura, T.; Yanaka, M.; Okamoto, S.; Handa, S.; Komatsu, Y.; Asano, T.; et al. Development of an Anti-Sheep Podoplanin Monoclonal Antibody PMab-256 for Immunohistochemical Analysis of Lymphatic Endothelial Cells. Monoclon. Antib. Immunodiagn. Immunother. 2020, 39, 82-90. [CrossRef]

168. Takei, J.; Furusawa, Y.; Yamada, S.; Nakamura, T.; Sayama, Y.; Sano, M.; Konnai, S.; Kobayashi, A.; Harada, H.; Kaneko, M.K.; et al. PMab-247 Detects Bear Podoplanin in Immunohistochemical Analysis. Monoclon. Antib. Immunodiagn. Immunother. 2019, 38, 171-174. [CrossRef] [PubMed]

169. Kato, Y.; Yamada, S.; Furusawa, Y.; Itai, S.; Nakamura, T.; Yanaka, M.; Sano, M.; Harada, H.; Fukui, M.; Kaneko, M.K. PMab-213: A monoclonal antibody for immunohistochemical analysis against pig podoplanin. Monoclon. Antib. Immunodiagn. Immunother. 2019, 38, 18-24. [CrossRef]

170. Kato, Y.; Furusawa, Y.; Itai, S.; Takei, J.; Nakamura, T.; Sano, M.; Harada, H.; Yamada, S.; Kaneko, M.K. Establishment of an Anticetacean Podoplanin Monoclonal Antibody PMab-237 for Immunohistochemical Analysis. Monoclon. Antib. Immunodiagn. Immunother. 2019, 38, 108-113. [CrossRef]

171. Furusawa, Y.; Yamada, S.; Nakamura, T.; Sano, M.; Sayama, Y.; Itai, S.; Takei, J.; Harada, H.; Fukui, M.; Kaneko, M.K.; et al. PMab235: A monoclonal antibody for immunohistochemical analysis against goat podoplanin. Heliyon 2019, 5, e02063. [CrossRef] [PubMed]

172. Furusawa, Y.; Yamada, S.; Itai, S.; Nakamura, T.; Takei, J.; Sano, M.; Harada, H.; Fukui, M.; Kaneko, M.K.; Kato, Y. Establishment of a monoclonal antibody PMab-233 for immunohistochemical analysis against Tasmanian devil podoplanin. Biochem. Biophys. Rep. 2019, 18, 100631. [CrossRef] [PubMed]

173. Furusawa, Y.; Kaneko, M.K.; Nakamura, T.; Itai, S.; Fukui, M.; Harada, H.; Yamada, S.; Kato, Y. Establishment of a Monoclonal Antibody PMab-231 for Tiger Podoplanin. Monoclon. Antib. Immunodiagn. Immunother. 2019, 38, 89-95. [CrossRef] 
174. Furusawa, Y.; Yamada, S.; Itai, S.; Sano, M.; Nakamura, T.; Yanaka, M.; Handa, S.; Mizuno, T.; Maeda, K.; Fukui, M.; et al. Establishment of Monoclonal Antibody PMab-202 Against Horse Podoplanin. Monoclon. Antib. Immunodiagn. Immunother. 2018, 37, 233-237. [CrossRef] [PubMed]

175. Yamada, S.; Itai, S.; Nakamura, T.; Yanaka, M.; Saidoh, N.; Chang, Y.W.; Handa, S.; Harada, H.; Kagawa, Y.; Ichii, O.; et al. PMab-52: Specific and Sensitive Monoclonal Antibody Against Cat Podoplanin for Immunohistochemistry. Monoclon. Antib. Immunodiagn. Immunother. 2017, 36, 224-230. [CrossRef]

176. Honma, R.; Ogasawara, S.; Kaneko, M.; Fujii, Y.; Oki, H.; Nakamura, T.; Takagi, M.; Konnai, S.; Kato, Y. PMab-44 Detects Bovine Podoplanin in Immunohistochemistry. Monoclon. Antib. Immunodiagn. Immunother. 2016, 35, 186-190. [CrossRef]

177. Honma, R.; Kaneko, M.K.; Ogasawara, S.; Fujii, Y.; Konnai, S.; Takagi, M.; Kato, Y. Specific Detection of Dog Podoplanin Expressed in Renal Glomerulus by a Novel Monoclonal Antibody PMab-38 in Immunohistochemistry. Monoclon. Antib. Immunodiagn. Immunother. 2016, 35, 212-216. [CrossRef]

178. Honma, R.; Fujii, Y.; Ogasawara, S.; Oki, H.; Liu, X.; Nakamura, T.; Kaneko, M.K.; Takagi, M.; Kato, Y. Establishment of a novel monoclonal antibody PMab-32 against rabbit podoplanin. Monoclon. Antib. Immunodiagn. Immunother. 2016, 35, 41-47. [CrossRef]

179. Oki, H.; Honma, R.; Ogasawara, S.; Fujii, Y.; Liu, X.; Takagi, M.; Kaneko, M.K.; Kato, Y. Development of Sensitive Monoclonal Antibody PMab-2 Against Rat Podoplanin. Monoclon. Antib. Immunodiagn. Immunother. 2015, 34, 396-403. [CrossRef]

180. Mitsunaga, M.; Ogawa, M.; Kosaka, N.; Rosenblum, L.T.; Choyke, P.L.; Kobayashi, H. Cancer cell-selective in vivo near infrared photoimmunotherapy targeting specific membrane molecules. Nat. Med. 2011, 17, 1685-1691. [CrossRef]

181. Kobayashi, H.; Furusawa, A.; Rosenberg, A.; Choyke, P.L. Near-infrared photoimmunotherapy of cancer: A new approach that kills cancer cells and enhances anti-cancer host immunity. Int. Immunol. 2021, 33, 7-15. [CrossRef] [PubMed]

182. Larson, S.M.; Carrasquillo, J.A.; Cheung, N.K.; Press, O.W. Radioimmunotherapy of human tumours. Nat. Rev. Cancer 2015, 15, 347-360. [CrossRef]

183. Gudkov, S.V.; Shilyagina, N.Y.; Vodeneev, V.A.; Zvyagin, A.V. Targeted Radionuclide Therapy of Human Tumors. Int. J. Mol. Sci. 2015, 17, 33. [CrossRef]

184. Sudo, H.; Tsuji, A.B.; Sugyo, A.; Saga, T.; Kaneko, M.K.; Kato, Y.; Higashi, T. Therapeutic efficacy evaluation of radioimmunotherapy with (90) Y-labeled anti-podoplanin antibody NZ-12 for mesothelioma. Cancer Sci. 2019, 110, 1653-1664. [CrossRef]

185. Miederer, M.; Scheinberg, D.A.; McDevitt, M.R. Realizing the potential of the Actinium-225 radionuclide generator in targeted alpha particle therapy applications. Adv. Drug Deliv. Rev. 2008, 60, 1371-1382. [CrossRef] [PubMed]

186. Tafreshi, N.K.; Doligalski, M.L.; Tichacek, C.J.; Pandya, D.N.; Budzevich, M.M.; El-Haddad, G.; Khushalani, N.I.; Moros, E.G.; McLaughlin, M.L.; Wadas, T.J.; et al. Development of Targeted Alpha Particle Therapy for Solid Tumors. Molecules 2019, $24,4314$. [CrossRef] [PubMed]

187. Sudo, H.; Tsuji, A.B.; Sugyo, A.; Kaneko, M.K.; Kato, Y.; Nagatsu, K.; Suzuki, H.; Higashi, T. Preclinical Evaluation of PodoplaninTargeted Alpha-Radioimmunotherapy with the Novel Antibody NZ-16 for Malignant Mesothelioma. Cells 2021, $10,2503$. [CrossRef] [PubMed]

188. Kato, Y.; Kaneko, M.K. A cancer-specific monoclonal antibody recognizes the aberrantly glycosylated podoplanin. Sci. Rep. 2014, 4, 5924. [CrossRef]

189. Miyazaki, A.; Nakai, H.; Sonoda, T.; Hirohashi, Y.; Kaneko, M.K.; Kato, Y.; Sawa, Y.; Hiratsuka, H. LpMab-23-recognizing cancer-type podoplanin is a novel predictor for a poor prognosis of early stage tongue cancer. Oncotarget 2018, 9, 21156-21165 [CrossRef]

190. Kaneko, M.K.; Ohishi, T.; Kawada, M.; Kato, Y. A cancer-specific anti-podocalyxin monoclonal antibody (60-mG(2a)-f) exerts antitumor effects in mouse xenograft models of pancreatic carcinoma. Biochem. Biophys. Rep. 2020, 24, 100826. [CrossRef]

191. Kaneko, M.K.; Nakamura, T.; Kunita, A.; Fukayama, M.; Abe, S.; Nishioka, Y.; Yamada, S.; Yanaka, M.; Saidoh, N.; Yoshida, K.; et al. ChLpMab-23: Cancer-Specific Human-Mouse Chimeric Anti-Podoplanin Antibody Exhibits Antitumor Activity via Antibody-Dependent Cellular Cytotoxicity. Monoclon. Antib. Immunodiagn. Immunother. 2017, 36, 104-112. [CrossRef] [PubMed]

192. Kaneko, M.K.; Yamada, S.; Nakamura, T.; Abe, S.; Nishioka, Y.; Kunita, A.; Fukayama, M.; Fujii, Y.; Ogasawara, S.; Kato, Y Antitumor activity of chLpMab-2, a human-mouse chimeric cancer-specific antihuman podoplanin antibody, via antibodydependent cellular cytotoxicity. Cancer Med. 2017, 6, 768-777. [CrossRef] [PubMed]

193. Ward, P.L.; Koeppen, H.; Hurteau, T.; Schreiber, H. Tumor antigens defined by cloned immunological probes are highly polymorphic and are not detected on autologous normal cells. J. Exp. Med. 1989, 170, 217-232. [CrossRef] [PubMed]

194. Schietinger, A.; Philip, M.; Yoshida, B.A.; Azadi, P.; Liu, H.; Meredith, S.C.; Schreiber, H. A mutant chaperone converts a wild-type protein into a tumor-specific antigen. Science 2006, 314, 304-308. [CrossRef]

195. Brooks, C.L.; Schietinger, A.; Borisova, S.N.; Kufer, P.; Okon, M.; Hirama, T.; Mackenzie, C.R.; Wang, L.X.; Schreiber, H.; Evans, S.V. Antibody recognition of a unique tumor-specific glycopeptide antigen. Proc. Natl. Acad. Sci. USA 2010, 107, 10056-10061. [CrossRef]

196. June, C.H.; O'Connor, R.S.; Kawalekar, O.U.; Ghassemi, S.; Milone, M.C. CAR T cell immunotherapy for human cancer. Science 2018, 359, 1361-1365. [CrossRef]

197. Waseda, M.; Kaneko, S. Podoplanin as an Attractive Target of CAR T Cell Therapy. Cells 2020, 9, 1971. [CrossRef]

198. Shiina, S.; Ohno, M.; Ohka, F.; Kuramitsu, S.; Yamamichi, A.; Kato, A.; Motomura, K.; Tanahashi, K.; Yamamoto, T.; Watanabe, R.; et al. CAR T Cells Targeting Podoplanin Reduce Orthotopic Glioblastomas in Mouse Brains. Cancer Immunol. Res. 2016, 4, 259-268. [CrossRef] 
199. He, Y.; Schreiber, K.; Wolf, S.P.; Wen, F.; Steentoft, C.; Zerweck, J.; Steiner, M.; Sharma, P.; Shepard, H.M.; Posey, A.; et al. Multiple cancer-specific antigens are targeted by a chimeric antigen receptor on a single cancer cell. JCI Insight 2019, 4, e130416. [CrossRef]

200. Sharma, P.; Marada, V.; Cai, Q.; Kizerwetter, M.; He, Y.; Wolf, S.P.; Schreiber, K.; Clausen, H.; Schreiber, H.; Kranz, D.M. Structure-guided engineering of the affinity and specificity of CARs against Tn-glycopeptides. Proc. Natl. Acad. Sci. USA 2020, 117, 15148-15159. [CrossRef] 